\title{
Holocene Sediment Types and Their Distribution in the Southern Persian Gulf
}

\author{
C. W. Wagner ${ }^{1}$ and C. van der Togt ${ }^{1}$
}

\section{ABSTRACT}

A simplified classification of the Holocene sediments based on textures and grain type results in fourteen major units, twelve of which are essentially carbonate in composition. A brief description and photographic illustration of these units, together with the sedimentary and diagenetic processes which have contributed to their formation, is designed to give the reader a broad but valid impression of Persian Gulf sediments.

The distribution of the fourteen sediment units throughout the Arabian parts of the basin, although complicated by numerous local bathymetric highs and depressions, is relatively simple. Because the Arabian sea floor slopes progressively from a windward shoreline to the basin center there is increasing protection from wave action towards the center of the basin. As a result sediments grade from skeletal, oolitic and pelletoidal sands (and muds in coastal lagoons) and fringing reefs, through an irregular zone of compound grain sands, into widespread skeletal muddy sands, and finally into basin center muds. These simple relationships vary laterally around the Arabian side of the gulf. Lateral variation is dependant upon orientation of the regional slope with respect to the prevailing NW wind-driven waves, angle of slope, and presence or absence of regional, structurally based barriers.

\section{INTRODUCTION}

\section{A. Genera1}

On first examination, samples of the surface sediments of the Southern Persian Gulf impress one with the monotony of their overall composition in that they are very largely made up of skeletal debris. However, a second more detailed look reveals an almost infinite variety within these skeletal sediments.

Several factors are involved in any attempt to subdivide such sediments: the number and nature of the samples taken (cores, grabs), their spacing, and the size of the area investigated. Except for several areas of rather close sampling (e.g. on, and around, local highs including Bu Tini or Halat Dalma), the majority of the lines extend from the Arabian coast towards the central part of the Gulf.

Although a considerable number of cores, and dredge samples were collected (some 550), the majority of the samples were taken with a 'Van Veen' grab (some 3200, including some 550 utilized by Houbolt, 1957). All of these were examined with

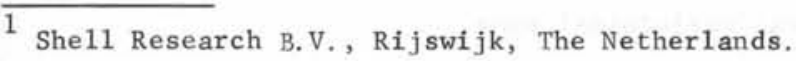


binocular microscope to ensure that a reasonable measure of the true texture was obtained (no resorting in the sample bags, etc.).

Full sieve and pipette analysis for grain size was carried out on relatively few samples (some 300), but (in keeping with our prime interest in the interpretation of ancient carbonates) a somewhat larger number (some 500) were impregnated with plastic, and polished slabs and/or large thin sections prepared. Analyses for total insoluble residues (some 600) and carbonate mineralogy (some 70) were carried out on sufficient samples mainly to characterise the defined sediment types.

\section{B. The method of subdivision}

In describing the sedimentary fabric of ancient carbonates, it is standard practice within the Shel1 Group to use the Dunham classification system (see Dunham, 1962). This descriptive system identifies depositional texture on the basis of grain or mud support (with 'grains' being larger than, and mud particles smaller than $20 \mu)$ and then identifies the fabric by reference to the dominant particle(s), producing compound terms such as 'crinoid grainstone', 'ooidal packstone', 'radiolarian wackestone', and 'coccolith mudstone' .

In our first inspection of the Persian Gulf sediments, an attempt was made to utilise the Dunham classes and thus preserve direct compatibility, but two factors prevented this. Firstly it became clear that the $20 \mu$ grain-size separation used by Dunham was neither practical nor meaningful in the Persian Gulf sediments, as the silt fraction $(63-20 \mu)$ was essentially inseparable from the mud fraction (sensu stricto $<20 \mu$ ) in sediment distribution. Secondly, in most of the muddy sediment samples obtained with a grab it is not always easy to distinguish grain from mud support, i,e. to distinguish a packstone from a wackestone. For these reasons, the Dunham terms were not used for the Persian Gulf sediments, being replaced by a simple threefold textural subdivision:

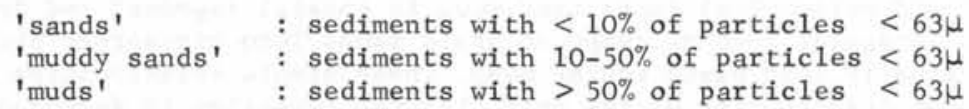

These textural terms were then qualified by the dominant grain type(s) to produce compound terms. Twelve distinctive types of carbonate sediment were recognised and labelled in this way. Two non-carbonate sediment types that have a distinctive distribution were also defined. The bound coral-algal masses forming the small areas of reef cannot be termed sediments and are not treated here but constitute distinctive carbonate rock types that would fall under Dunham's term 'boundstone'.

\section{THE MAIN TYPES OF SEDIMENT IN THE SOUTHERN PERSIAN GULF}

\section{A. Grouping of the sediment types}

Fourteen types of sediment have been defined and their distribution illustrated by means of profiles and a map appended at the back of this volume. The sediment types are discussed in the following order:

\section{Carbonates}

\section{Sands}

$\begin{array}{cc}\text { Type no. } & 1 \\ \text { " } & 2 \\ \text { " } & 3 \\ \text { " } & 4 \\ \text { " } & 5 \\ \text { " } & 6 \\ \text { " } & 7\end{array}$

Lamellibranch sand

Compound grain/lamellibranch sand

Large perforate-foraminiferal sand

Coral/algal sand

Imperforate foraminferal/pelletoidal sand

Gastropod sand

Ooidal sand (oolite) 


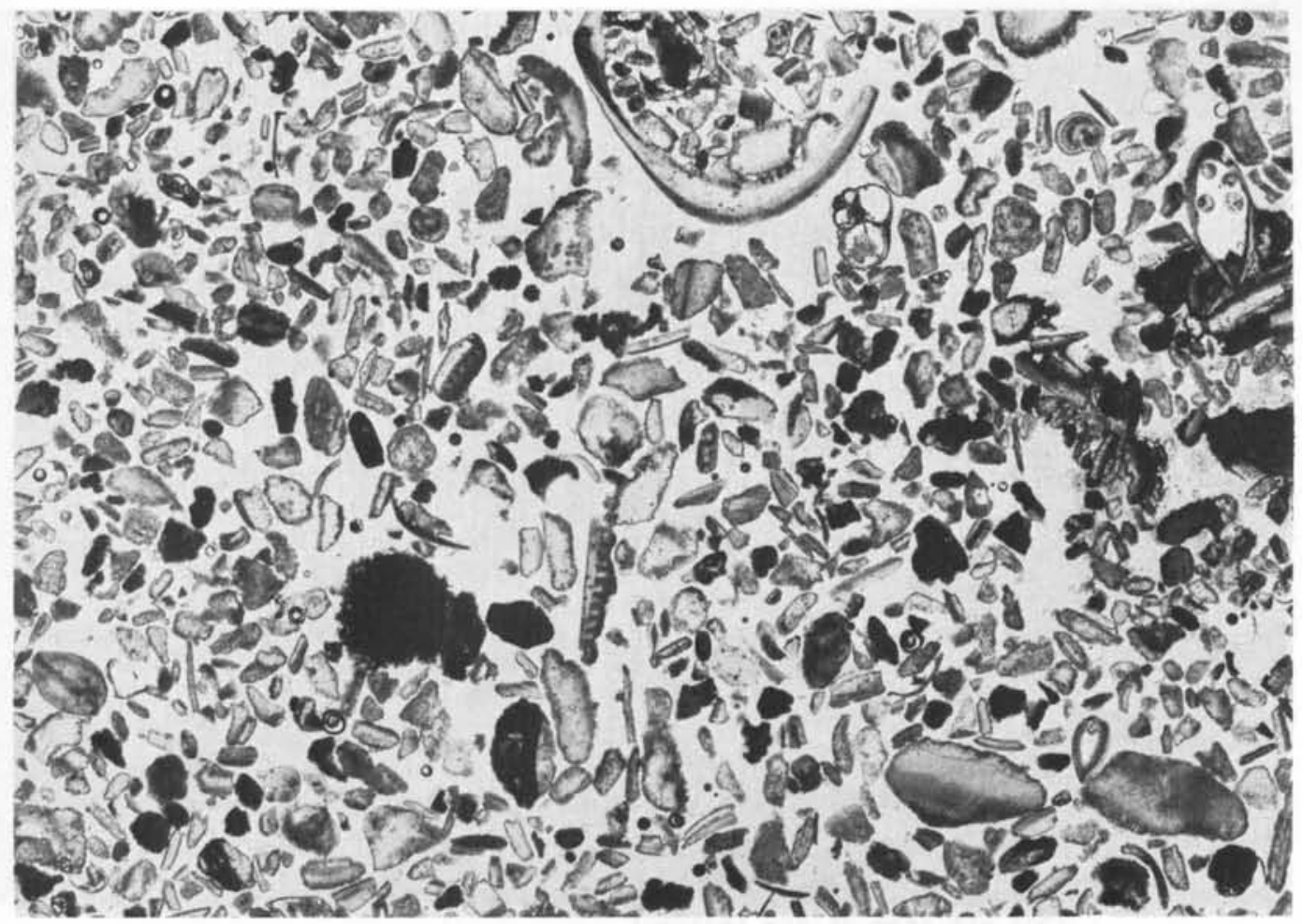

Fig. 1. Lamellibranch sand - Thin section of sample T 666, 10x

Note: Micritization of skeletal grains; some grains exhibit only a micritized periphery, others have been nearly completely micritized, such that the original skeltal structure becomes obscured.

The composition is very monotonous, the greater part of the grains being lamellibranch fragments.

Bulk carbonate composition:

$\begin{array}{lr}\text { Aragonite } & 85 \% \\ \text { Mg calcite } & 10 \% \\ \text { Calcite } & 5 \%\end{array}$

Sorting: moderate

Foraminiferal number: 200
Grain size:

$$
\begin{aligned}
& >2 \mathrm{~mm} \quad 7 \% \\
& 2-0.063 \mathrm{~mm} 90 \% \\
& <0.063 \mathrm{~mm} 3 \%
\end{aligned}
$$

Bulk insoluble residue: $0.5 \%$

Foraminiferal composition:

Calcareous imperforate $15 \%$

Calcareous perforate $15 \%$

Arenaceous $\quad 70 \%$ 


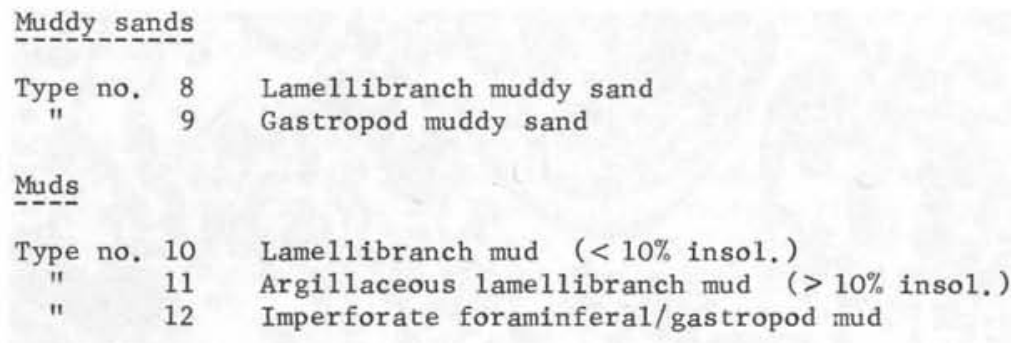

\section{Non-Carbonates}

$\begin{array}{cl}\text { Type no. } 13 & \text { Quartz sand (including muddy quartz sand) } \\ 14 & \text { Sedimentary gypsum (precipitated in coastal lagoons) }\end{array}$

Twelve of the fourteen sediment types are illustrated on the following pages by one or two thin section photomicrographs of the plastic impregnated sediment. For each illustrated sample the following parameters are also given.

N.B. These parameters are those of the individual samples and are not to be taken as mean or average values for all samples of that sediment type.

(a) Bulk carbonate composition: determined by means of an X-ray spectrometer (the results of all such analyses are collected in table I).

(b) Sorting: estimated visually as either 'good', 'moderate' or 'poor' .

(c) Foraminiferal number: the number of foraminiferal tests (1arger than 75 $\mu$ ) per gram of dry sediment.

(see Hughes Clarke \& Keij, this volume)

(d) Grain size: determined by sieve analysis.

(e) Bulk insoluble residue: residue after digestion in 2 Normal hot HCL.

(f) Foraminiferal composition: the relative proportions (in the fraction $>75 \mu$ ) of the three major foraminiferal groups 'calcareous imperforate', 'calcareous perforate' and 'arenaceous' (see Hughes Clarke \& Keij, this volume).

\section{B. Description of the sediment types}

\section{SANDS}

Type no. 1 Lamellibranch sand (Fig. 1)

(a) Sedimentological description

The lamellibranch sand consists of rounded to angular, moderately sorted, lamellibranch fragments of medium sand size. Compound grains form a minor constituent. Mud matrix average $4 \%$ of the sediment. Bulk insoluble residue averages $1 \%$, and does not exceed $5 \%$.

(b) Faunal/floral elements

Most skeletal grains are lamellibranch shell fragments, small whole she11s generally being present. Recognisable lamellibranchs belong mainly to the species Ervillea purpurea. Coralline algal debris is often associated with the lamellibranch fragments, but is subordinate. Foraminifera, echinoid fragments and small gastropods form minor constituents. 


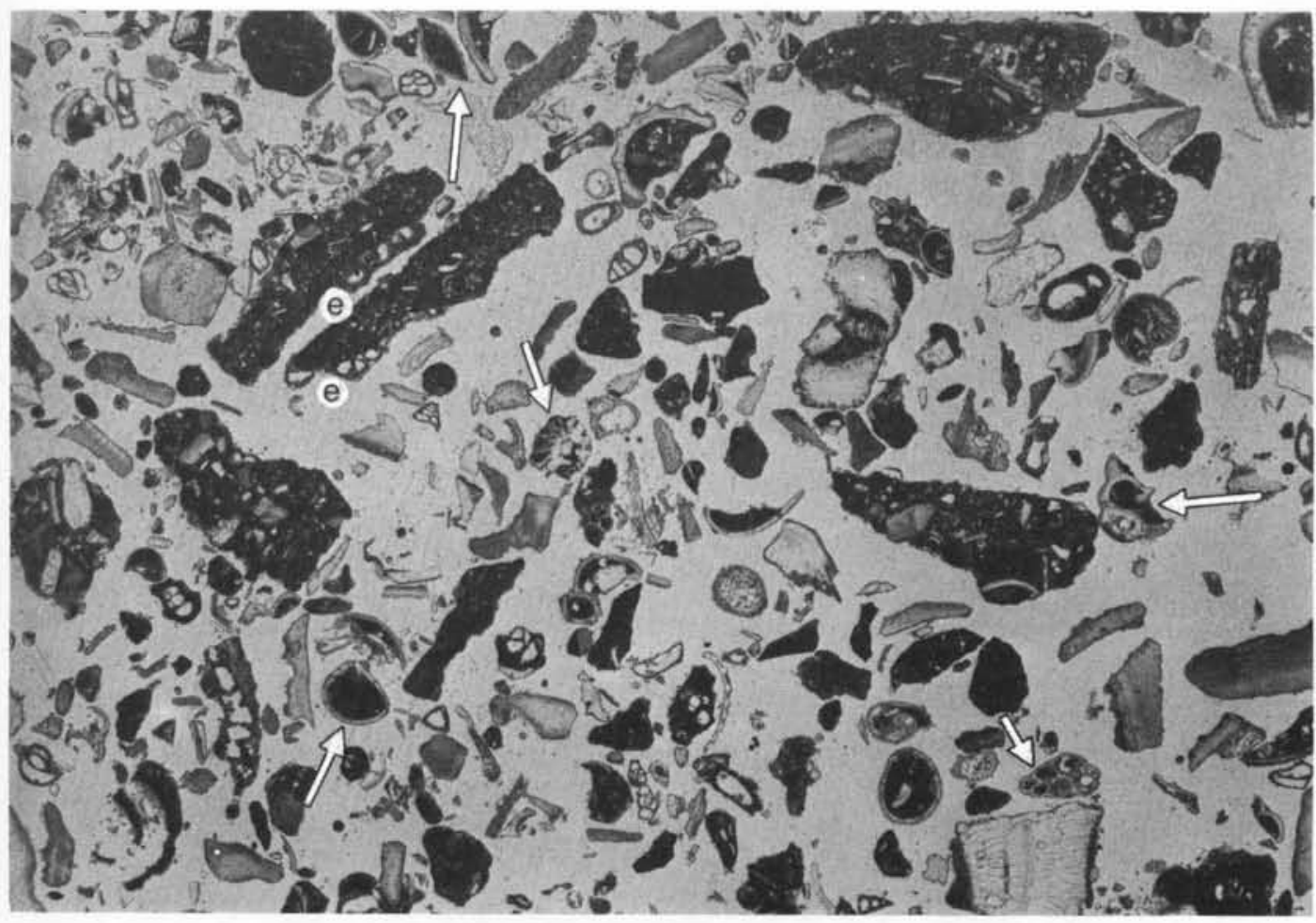

Fig. 2. Compound grain/lamellibranch sand - Thin section of sample T 101, 10x Note: Faint micritized periphery on nearly all skeletal grains.

Infill of cryptocrystalline carbonate in interior of mollusks (arrows)

Greater variety in sikeletal material than in the Lamelibranch sand (Type 1)

Presence of encrusting Foraminifera on certain compound grains (e)

Bulk carbonate composition:

$\begin{array}{ll}\text { Aragonite } & 60 \% \\ \text { Mg calcite } & 30 \% \\ \text { Calcite } & 10 \%\end{array}$

Sorting: moderate

Foraminiferal number: 360
Grain size:

$\begin{array}{lr}>2 \mathrm{~mm} & 11 \% \\ 2-0.063 \mathrm{~mm} & 81 \% \\ <0.063 \mathrm{~mm} & 8 \%\end{array}$

Bulk insoluble residue: $0.5 \%$

Foraminiferal composition:

Calcareous imperforate $47 \%$

Calcareous perforate $1 \%$

Arenaceous $52 \%$ 


\section{(c) Synsedimentary diagenetic features}

Most skeletal grains have been algally bored, but still retain traces of their primary structure. Some articulated valves are filled with fibrous aragonite crystals. However, this infilling is more characteristic of the compound grain/lamellibranch sands (type 2). Compound grains are relatively rare.

(d) Relation to environment

The recognisable lamellibranchs are infaunal (Hughes Clarke \& Keij, this volume) and may be regarded as indigenous or semi-indigenous elements. The minor coralline algal debris is apparently exotic, as these algae require a hard substratum and are derived from adjacent hard-rock areas, including local offshore highs.

$\mathrm{C}^{14}$ bulk dating indicates that the lamellibranch sands are not older than $2120 \pm 150$ years, and thus represent Holocene accumulation. The lamellibranch sands occur in shallow marine, nonrestricted, high-energy environments. The distribution also seems to depend upon the submarine topography, i.e. the relative absence of hard-rock substratum.

Type no. 2 Compound grain/lamellibranch sand (Fig. 2)

(a) Sedimentological description

The compound grain/lamellibranch sand consists of angular skeletal fragments and angular to rounded compound grains, the sediment being coarse and moderately sorted.

Mud matrix averages $4 \%$ of the sediment, while bulk insoluble residue averages $1 \%$ and does not exceed $3 \%$.

(b) Fauna1/floral elements

Skeletal grains are mainly lamellibranchs, both fragments and whole shells. Small gastropods, larger Foraminifera (mainly Operculina), smaller Foraminifera and echinoid debris also occur.

\section{(c) Synsedimentary diagenetic features}

Nearly all skeletal grains exhibit a thin, algally bored periphery. Many shells are infilled with very fine, cryptocrystalline carbonate or fibrous aragonite crystals. Compound grains consist of lithified skeletal material similar to the loose sediment and therefore possibly lithified in situ. They may, however, also be pieces broken from larger scale lithified units and transported into the area.

Most particles have a reddish-brown colouration, which is very typical for this sediment type.

(d) Relation to environment

$\mathrm{C}^{14}$ bulk dating* of the reddish-brown components of the sediment show that their age ranges from $2460 \pm 140$ to $3020 \pm 160$ years, indicating that the sediment is the product of present sēa level. Thesé relatively old dates suggest, however, that sedimentation is slow relative to that of other sediment types. The compound grain/lamellibranch sands occur in shallow-marine, nonrestricted, moderate-energy

* See Fig. 18 and Table I for available $\mathrm{C}^{14}$ datings. 


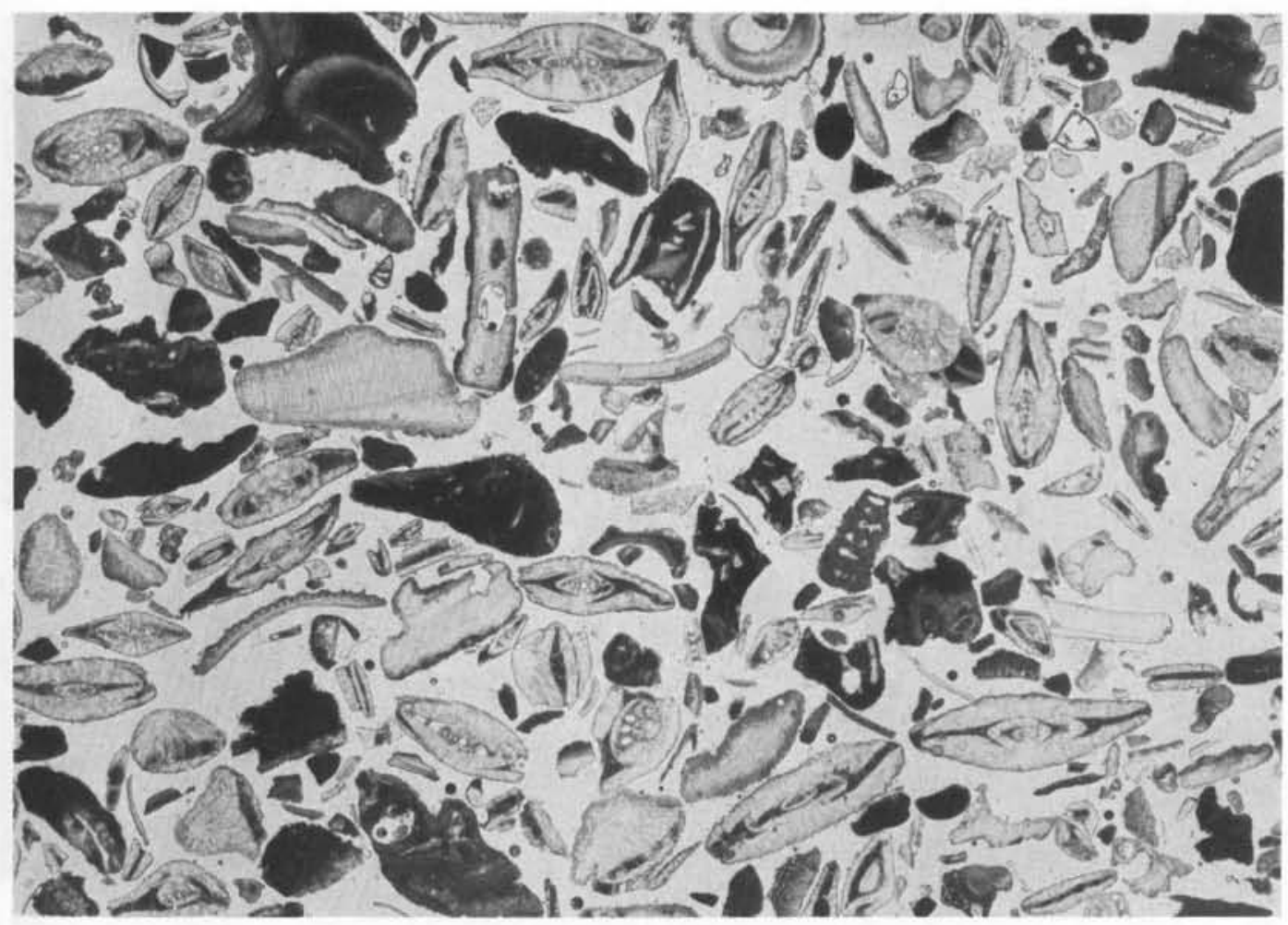

Fig. 3. Large perforate foraminiferal sand - Thin section of sample T 1139, 10x

Note: Strong degree of micritization of some particles in contrast to faint micrite periphery of most skeletal grains.

Monotony in skeletal composition (majority of particles represent whole tests of perforate large Foraminifera).

Cryptocrystalline material in foraminiferal chambers.

Bulk carbonate composition:

Aragonite $\quad 10 \%$

$\mathrm{Mg}$ calcite $90 \%$

Sorting: moderate

Foraminiferal number: 400
Grain size:

$\begin{array}{lr}>2 \mathrm{~mm} & 3 \% \\ 2-0.063 \mathrm{~mm} & 95 \% \\ <0.063 \mathrm{~mm} & 2 \%\end{array}$

Bulk insoluble residue: $1.2 \%$

Foraminiferal composition:

Calcareous imperforate $13 \%$

Calcareous perforate $72 \%$

Arenaceous $\quad 15 \%$ 


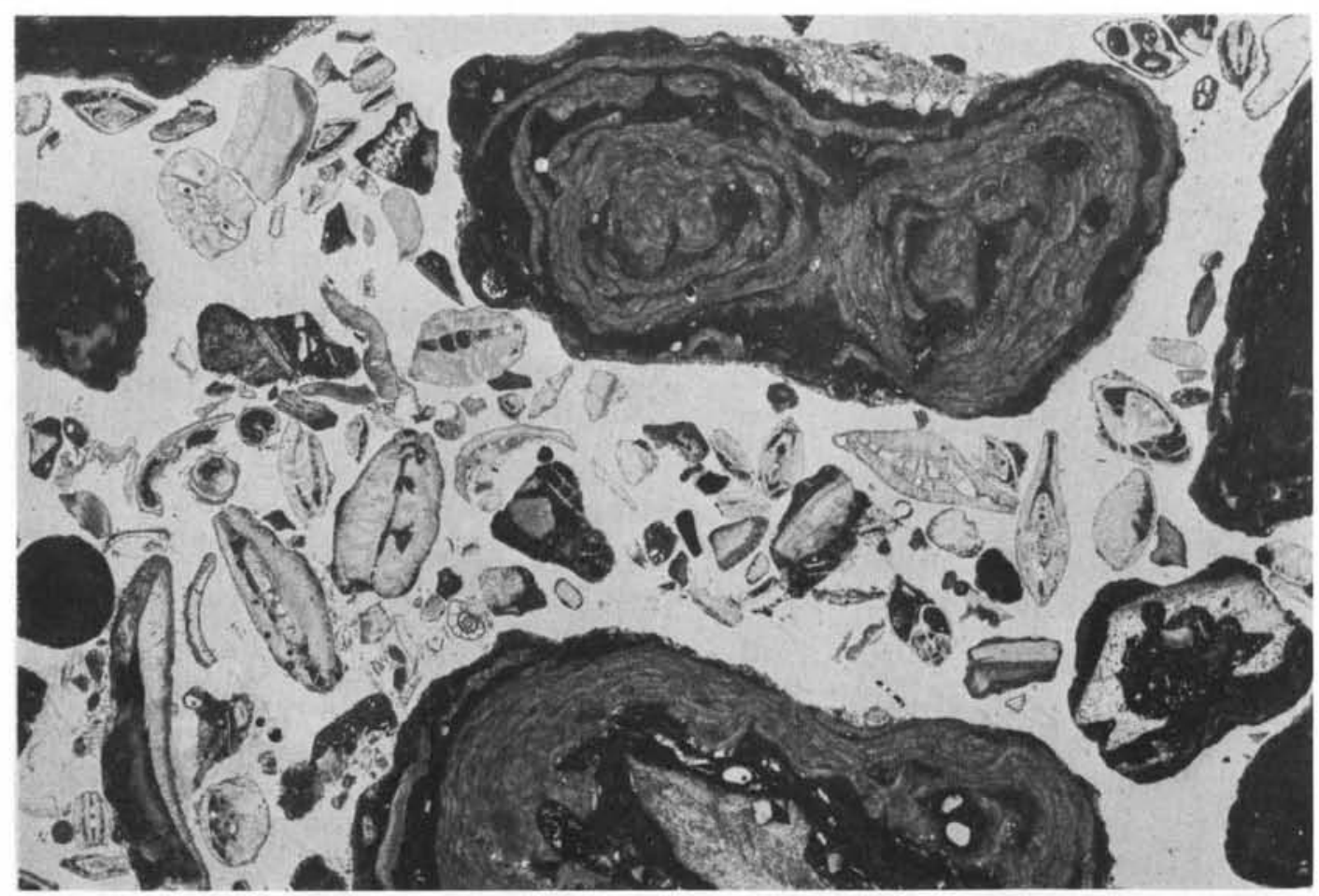

Fig. 4. Large perforate foraminiferal sand - Thin section of sample $\mathrm{T} 66,10 \mathrm{x}$

Note: Large oncoids consisting of various types of melobesioid algae which have been bored by sponges and are sometimes encrusted with various Foraminifera, worms, etc.

Cryptocrystalline carbonate material in foraminiferal chambers.

Relatively large number of compound grains.

Bulk carbonate composition:

\begin{tabular}{lr}
\hline Aragonite & $30 \%$ \\
Mg calcite & $65 \%$ \\
Calcite & $5 \%$
\end{tabular}

Foraminiferal number: 600
Grain size:

$\begin{array}{lr}>2 \mathrm{~mm} & 35 \% \\ 2-0.063 \mathrm{~mm} & 61 \% \\ <0.063 \mathrm{~mm} & 4 \%\end{array}$

Bulk insoluble residue: $1.1 \%$

Foraminiferal composition:

Calcareous imperforate $18 \%$

Calcareous perforate $61 \%$

Arenaceous $21 \%$ 


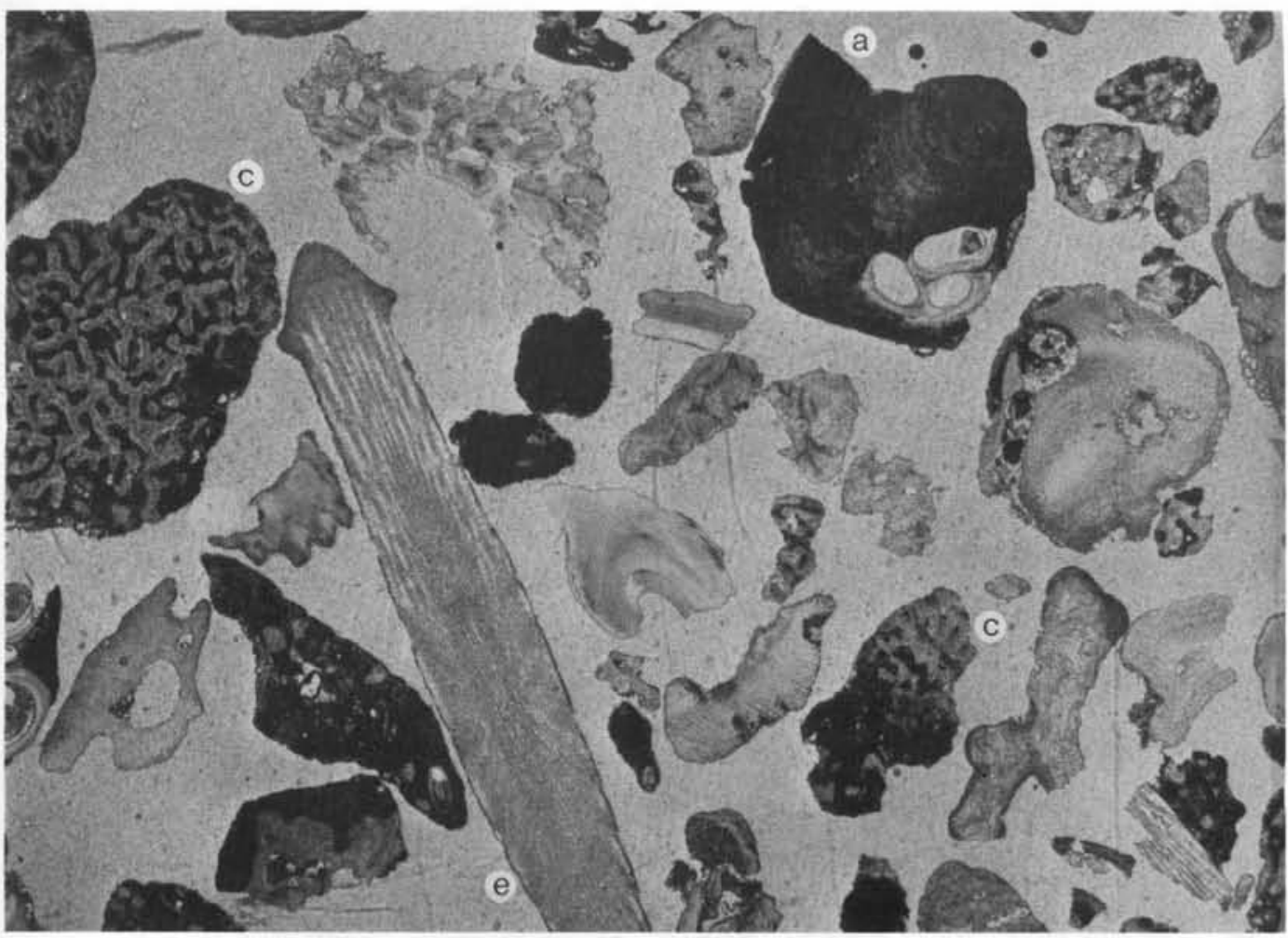

Fig. 5. Coral/algal sand - Thin section of sample $\mathrm{T} 284,10 \mathrm{x}$

Note: Skeletal elements for the greater part of epifaunal/floral origin ( $c=$ coral, $a=$ coralline algae, $e=$ epifaunal echinoid spine)

Presence of coral debris indicating relatively limited sediment transport (as it is easily broken down into mud-sized material).

Bulk carbonate composition:

$\begin{array}{lr}\text { Aragonite } & 65 \% \\ \text { Mg calcite } & 30 \% \\ \text { Calcite } & 5 \%\end{array}$

Sorting: poor

Foraminiferal number: 40
Grain size:

$\begin{array}{lr}>2 \mathrm{~mm} & 19 \% \\ 2-0.063 \mathrm{~mm} & 79 \% \\ <0.063 \mathrm{~mm} & 2 \%\end{array}$

Bulk insoluble residue: $0.4 \%$

Foraminiferal composition:

Calcareous imperforate $17 \%$

Calcareous perforate $\quad 78 \%$

Arenaceous

$5 \%$ 


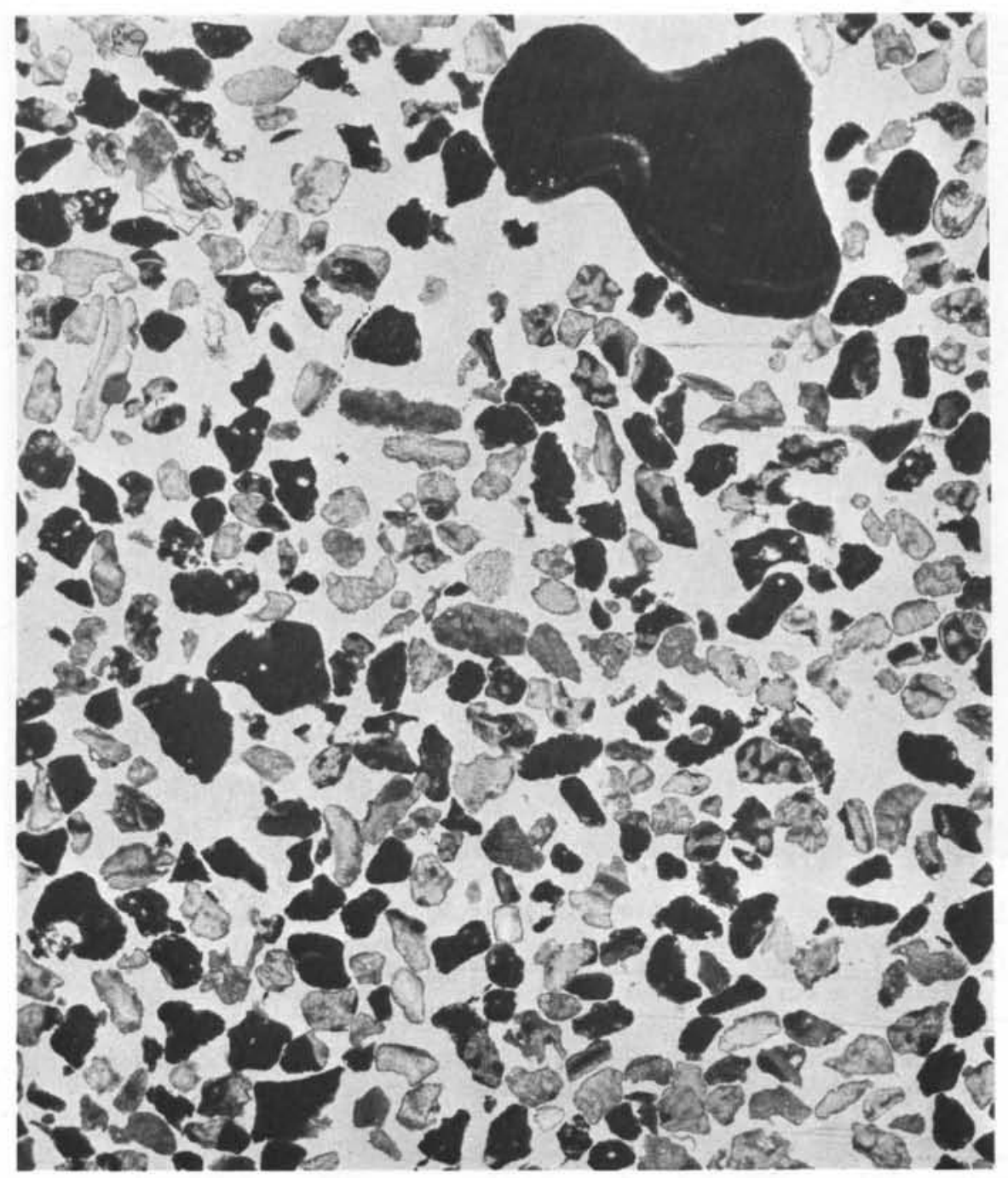

Fig. 6. Coral/algal sand - Thin section of sample T 741, 10x

Note: Coralline algal fragments bored by sponges. Only faint development of micrite peripheries on grains.

Bulk carbonate composition:

$\begin{array}{ll}\text { Aragonite } & 50 \% \\ & 50 \%\end{array}$

Sorting: moderate

Foraminiferal number: 30
Grain size:

$\begin{array}{cr}>2 \mathrm{~mm} & 11 \% \\ 2-0.063 \mathrm{~mm} & 86 \% \\ <0.063 \mathrm{~mm} & 3 \%\end{array}$

Bulk insoluble residue: $0.2 \%$

Foraminiferal composition:

Calcareous imperforate $90 \%$

Calcareous perforate $10 \%$ 
environments; energy being somewhat lower than that in the lamellibranch-sand environment (skeletal particles show less abrasional rounding), but still high enough to prevent the deposition of carbonate mud. The low rate of sedimentation, together with relatively little movement of the sediment, seems to favour incipient synsedimentary lithification (Shinn, 1969) and may have led to the high content of compound grains.

Type no. 3 Large perforate-foraminiferal sand (Figs. $3+4$ )

\section{(a) Sedimentological description}

This type of sediment consists mainly of whole tests of perforate large Foraminifera together with varying amounts of skeletal (red algal) oncoids. Because locally produced whole tests make up the majority of the particles, roundness, average grain size and sorting have little sedimentological meaning.

Mud matrix averages $1 \%$ and does not exceed $5 \%$. Bulk insoluble residue averages $1 \%$ and does not exceed $5 \%$.

(b) Fauna1/floral elements

The perforate large Foraminifera are Heterostegina and/or Amphistegina. The oncoids are formed by melobesioid algae (several genera), which frequently coat mollusk shells or fragments.

Lamellibranch fragments, small gastropods and smaller Foraminifera form a minor constituent of the sediment.

(c) Synsedimentary diagenetic features

Grains show a varying degree of algal boring, but in general only a thin bored periphery is developed. Large foraminiferal chambers are often filled with cryptocrystalline carbonate cement and compound grains sometimes occur.

(d) Relation to environment

These large foraminiferal sands are concentrated on the tops of unrestricted offshore highs at depths of 10-20 fathoms, where they seem to live in association with coralline algae.

Type no. 4 Coral/algal sand (Figs. $5+6$ )

(a) Sedimentological description

The coral/algal sands consist mainly of rounded skeletal fragments, which are moderately to badly sorted and generally of coarse sand-size. The mud matrix averages $3 \%$ and is always less than $6 \%$. Bulk insoluble residue averages $1 \%$ and does not exceed $6 \%$.

(b) Fauna1/f1oral_elements

The dominant skeletal particles are fragments of corals and coralline algae. Mollusk and echinoid fragments and Foraminifera also occur. Most fragments belong to epifaunal/flora groups.

(c) Synsedimentary diagenetic features

Particles in general do not show algally bored peripheries. Compound grains are rare. 


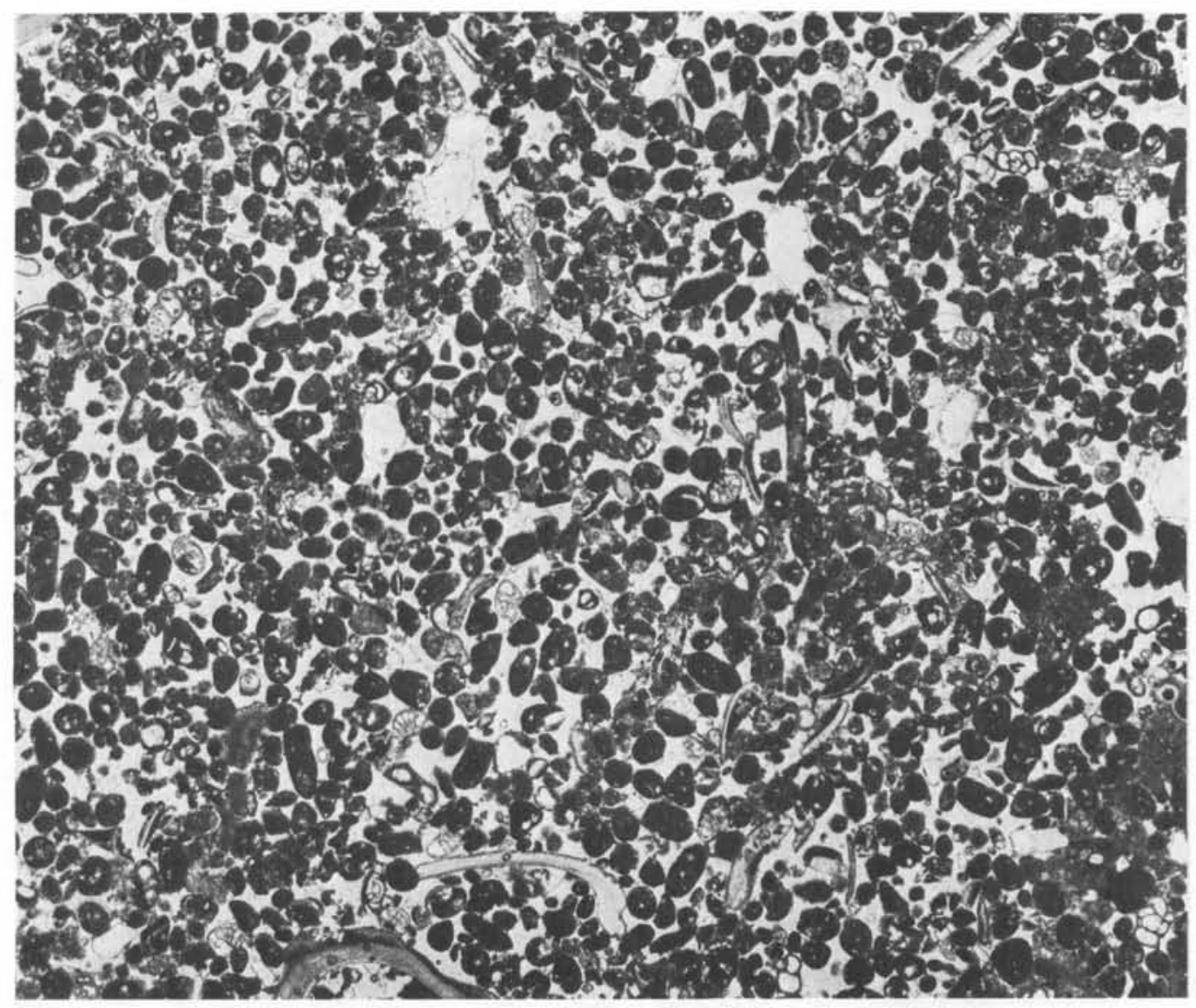

Fig. 7. Imperforate foraminiferal/pelletoid sand - Thin section of sample D 756, 12.5x

Bulk carbonate composition

$\begin{array}{ll}\text { Aragonite } & 50 \% \\ \text { Mg calcite } & 30 \% \\ \text { Calcite } & 20 \%\end{array}$

Sorting: moderate to good

Foraminiferal number: 1200
Grain size:

$\begin{array}{lr}>2 \mathrm{~mm} & 1 \% \\ 2-0.063 \mathrm{~mm} & 92 \% \\ <0.063 \mathrm{~mm} & 7 \%\end{array}$

Bulk insoluble residue: $8.5 \%$

Foraminiferal composition:

Calcareous imperforate : $70 \%$ Calcareous perforate : $29 \%$ Arenaceous 


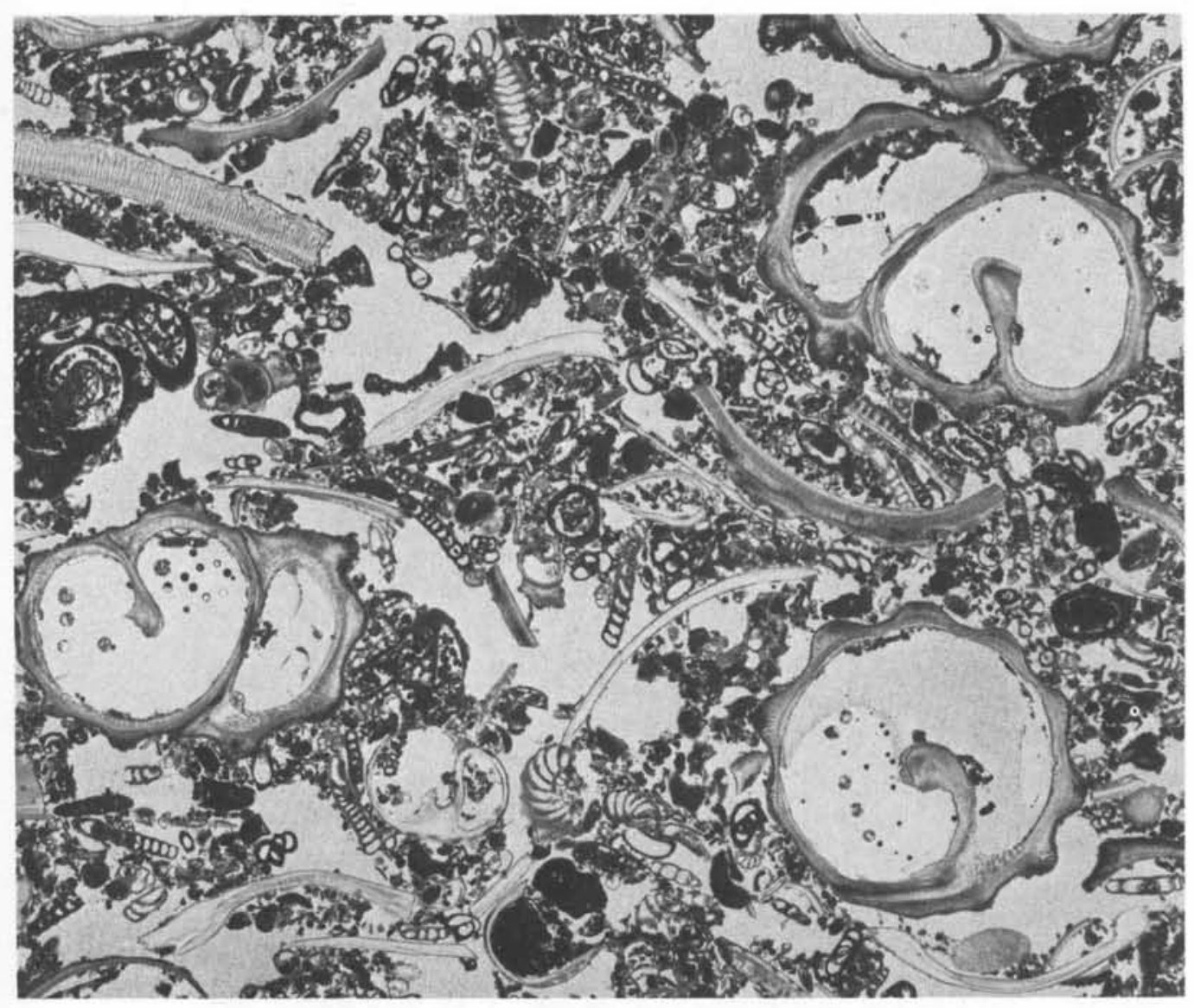

Fig. 8. Gastropod sand - Thin section of sample Q 27 (10), 10x

Note: Abundance of imperforate Foraminifera

Only faint development of micrite peripheries on certain grains.

Bulk carbonate composition:

Aragonite: $\quad 30 \%$

Mg calcite: $\quad 70 \%$

Sorting: poor

Foraminiferal number: 5720
Grain size:

$\begin{array}{cr}>2 \mathrm{~mm} & 11 \% \\ 2-0.063 \mathrm{~mm} & 81 \% \\ <0.063 \mathrm{~mm} & 8 \%\end{array}$

Bulk insoluble residue: $2.7 \%$

Foraminiferal composition:

Calcareous imperforate $87 \%$

Calcareous perforate $12 \%$

Arenaceous $1 \%$ 
(d) Re1ation to environment

The coral/algal sands are detritus from organic reefs developed on areas of hard rock bottom, e.g. on the windward sides of islands. The sands accumulate around these source areas, particularly down wind as "sand-tails" or bars (see Purser, this volume). They may also form coastal spits where the reefs fringe the Arabian coastline (see Shinn, in this volume).

The coral/algal sands occur in relatively small patches. Deposition is in unrestricted, high-water-energy conditions where rates of sedimentation are relatively high, which probably prevents attack by boring algae.

Type no. 5 Imperforate foraminiferal/pelletoidal sand (Fig. 7)

(a) Sedimentological description

This sediment is extremely variable in character. Its most constant components are imperforate Foraminifera and algally bored skeletal grains or pelletoids.

Faecal pellets are often dominant and compound grains are also common. Traces of insoluble residue (generally quartz) are often present.

(b) Faunal/floral elements

These are dominated by miliolid and peneroplid Foraminifera with variable amounts of smal1 perforate Foraminifera.

High-spired cerithiid gastropods are often abundant, as are diverse lamellibranchs, dasyclad algae and ostracods. Some grains exhibit algally bored peripheries.

(c) Synsedimentary diagenetic features

Gastropods and articulated lamellibranch shells are very often filled with fibrous aragonite and cryptocrystalline cements.

(d) Relation to environment

These carbonate sands characterise, but are not limited to, restricted environments. They nearly always occur in moderate to low energy settings in water depths of less than $5 \mathrm{~m}$. They are typical of wide tidal flats. Virtually al1 grains are derived locally, often from the shallow lagoonal environments adjacent to the tidal flats.

Type no. 6 Gastropod sand (Fig. 8)

(a) Sedimentological description

These sediments consist of poorly sorted, medium to coarse particles composed mainly of high-spired gastropods, and coarsely broken lamellibranchs in subequal amounts. Accessory particles include pelletoids, large compound grains, and imperforate Foraminifera. Traces of insoluble residue (mainly quartz) are often present.

(b) Faunal/floral elements

A low-diversity fauna of gastropods and lamellibranchs (the former being more abundant) are characteristic of these sediments. Imperforate Foraminifera (peneroplids and miliolids) are often abundant. 


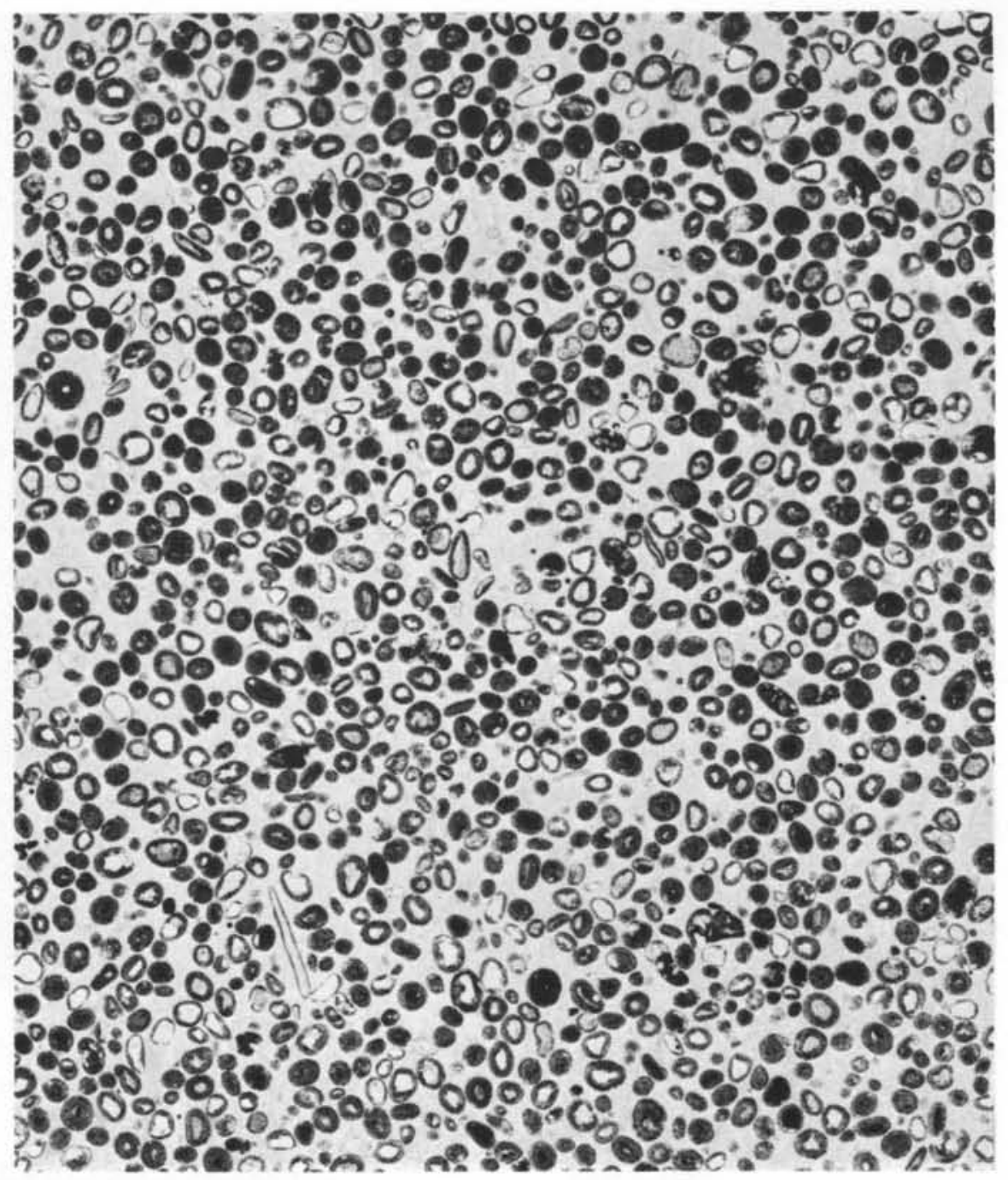

Fig. 9. Ooidal sand (oolite) - Thin section of sample D 843, 14x

Note: Good sorting and aragonitic coating of virtually all particles

Bulk carbonate composition:

$\begin{array}{ll}\text { Aragonite } & 90 \% \\ \text { Mg calcite } & 10 \%\end{array}$

Sorting: good
Grain size:

$\begin{array}{ll}>2 \mathrm{~mm} & - \\ 2.0 .063 \mathrm{~mm} & 97 \% \\ <0.063 \mathrm{~mm} & 3 \%\end{array}$

Bulk insoluble resıdue: $15.3 \%$

Foraminiferal composition:

Calcareous imperforate $52 \%$

Calcareous perforate $48 \%$ 


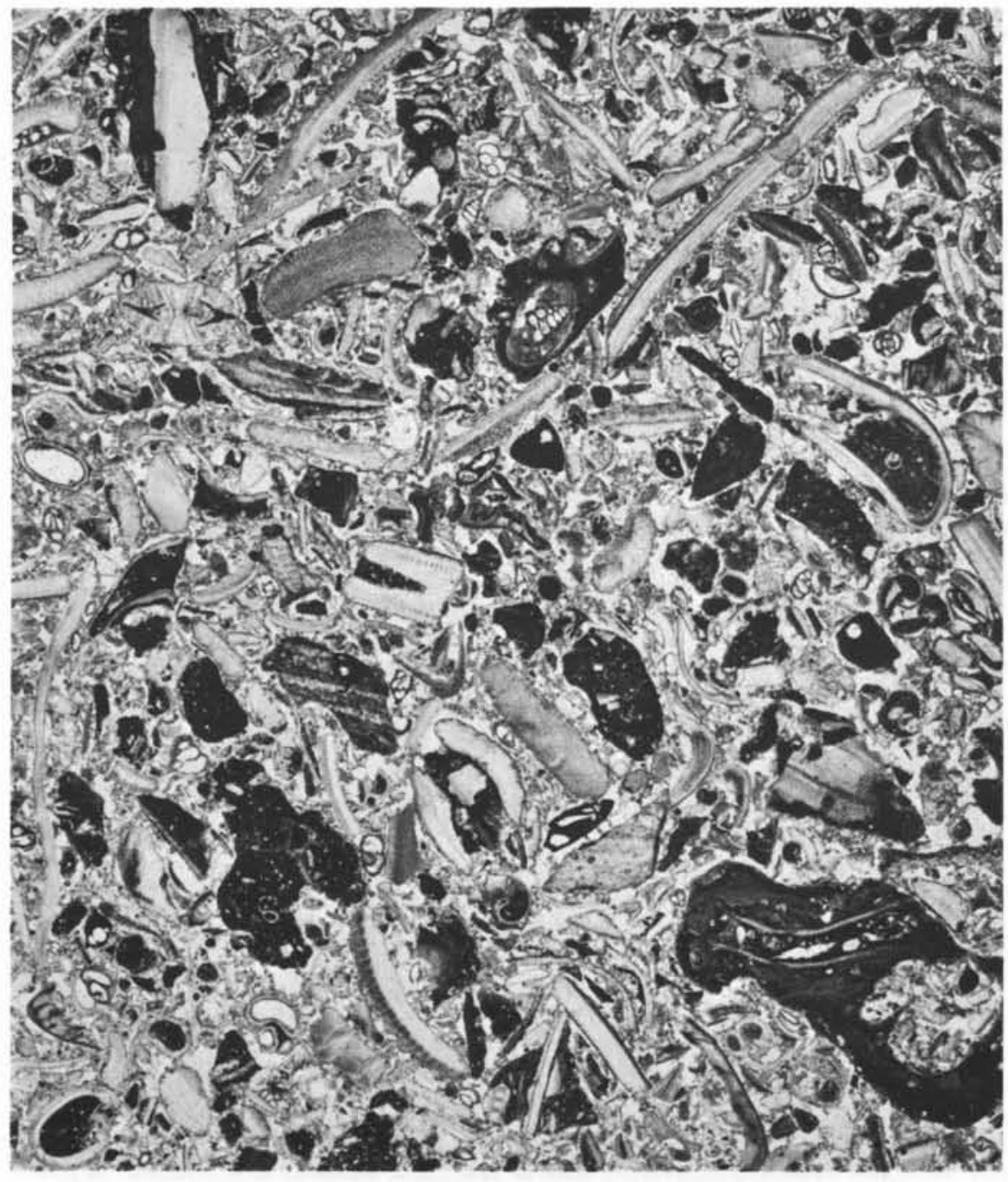

Fig. 10. Lamellibranch muddy sand - Thin section of sample T 19, 10x Note: "Black" compound particles and certain Foraminifera and other skeletal remains, Virtual absence of micritized peripheries on skeletal grains

Bulk carbonate composition:

Aragonite

Mg calcite

$55 \%$

Calcite

$35 \%$

$10 \%$

Sorting: poor

Foraminiferal number: 800
Grain size:

$\begin{array}{ll}>2 \mathrm{~mm} & 11 \% \\ 2-0.063 \mathrm{~mm} & 75 \% \\ <0.063 \mathrm{~mm} & 14 \%\end{array}$

Bulk insoluble residue: $1.3 \%$

Foraminiferal composition:

Calcareous imperforate $55 \%$

Calcareous perforate $15 \%$

Arenaceous $\quad 30 \%$ 


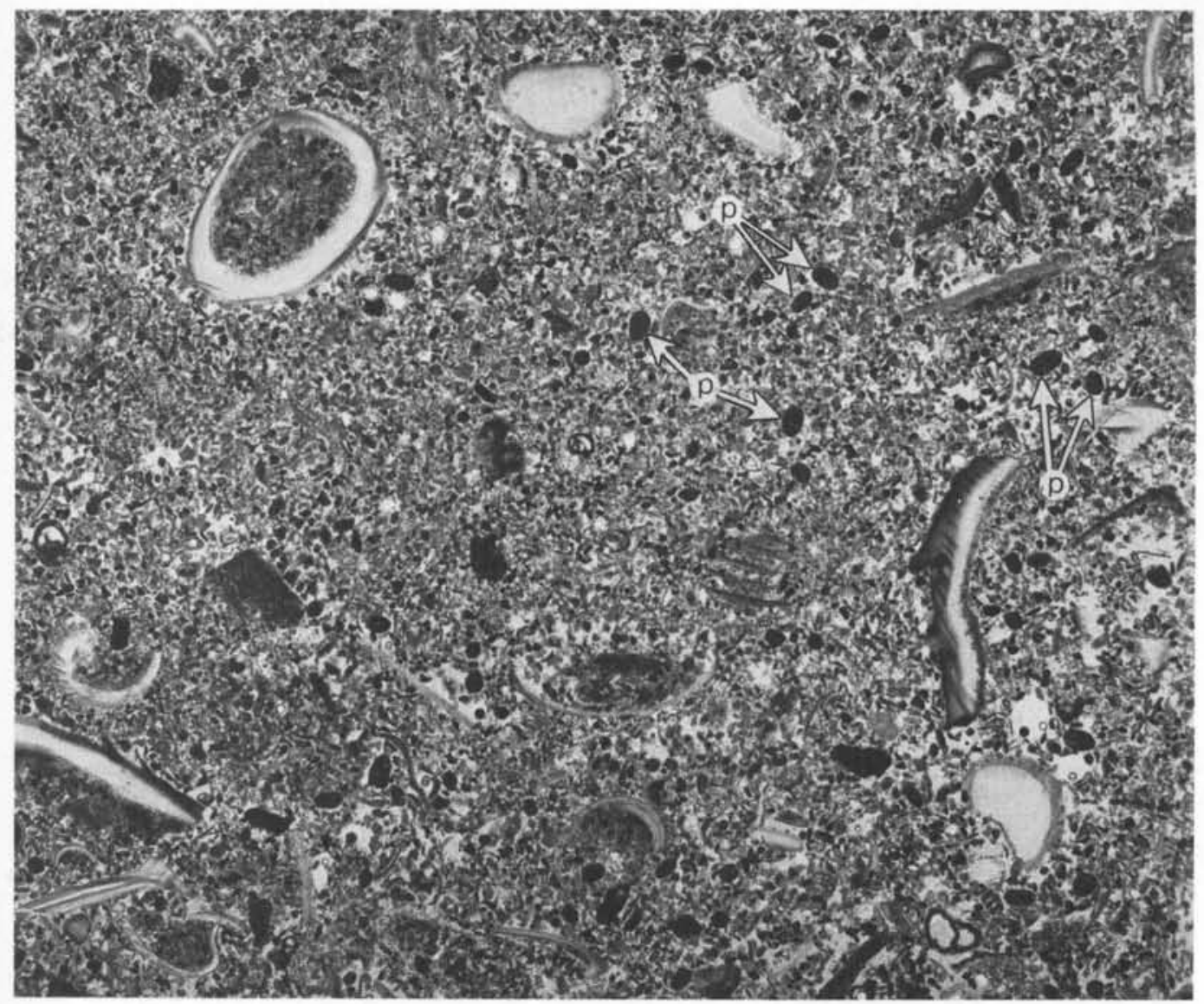

Fig. 11. Lamellibranch muddy sand - Thin section of sample T $1673,10 \mathrm{x}$

Note: Average grain size much smaller than in sample T 19 (Fig. 10) Soft faecal pellets (p) and blackened particles.

Bulk carbonate composition:

Aragonite $55 \%$

$\mathrm{Mg}$ calcite $\quad 30 \%$

Calcite $10 \%$

Dolomite

Sorting: poor

Foraminiferal number: 10730
Grain size:

$\begin{array}{lr}>2 \mathrm{~mm} & 2 \% \\ 2-0.0 .63 \mathrm{~mm} & 63 \% \\ <0.063 \mathrm{~mm} & 35 \%\end{array}$

Bulk insoluble residue: $3 \%$

Foraminiferal composition:

Calcareous imperforate $52 \%$

Calcareous perforate $26 \%$

Arenaceous $22 \%$ 


\section{(c) Synsedimentary diagenetic features}

These include a high degree of algal micritization of many grains, and the formation of sand-sized compound grains by the precipitation of fibrous or cryptocrystalline cements.

(d) Relation to environment

These sediments are confined to depths generally less than $5 \mathrm{~m}$ and characterise, but are not limited to, restricted environments. As such, these sediments occur in protected coastal embayments and on the lee sides of coastal barrier complexes. The abundance of gastropods and peneroplid (1arge imperforate) Foraminifera is probably due to the presence of widespread rock substrates supporting abundant brown algae.

Type no. 7 Ooidal sand (oolite) (Fig. 9)

(a) Sedimentological description

These sediments consist mainly of ooids, but molluskan fragments can occur in minor amounts. The ooidal grains often have quartz nuclei.

(b) Faunal/floral elements

Scattered lamellibranchs and gastropod shell fragments are often present; most are not indigenous to the oolite-forming environment.

(c) Synsedimentary diagenetic features

The rare gastropods and articulated lamellibranchs are often infilled with fibrous or cryptocrystalline cements.

(d) Relation to environment

The oolitic sediments occur in areas of active tidal currents. These currents are often reversible in direction and maintain the grains within the area in which frequent movement can occur. The environments in which the oolites are found are always within a few kilometres of the continental shoreline, in water depths of less than $3 \mathrm{~m}$ and with salinities only slightly above normal. Oolites are apparently readily transported and most tend to accumulate on beaches or as aeolian dunes. This is especially common along the Trucial Coast. Scattered ooliths can occur at all depths within the Gulf, but $\mathrm{C}^{14}$ dating shows that all deeper occurrences are relict, having been formed earlier during the Holocene transgression. They have subsequently been intermixed with contemporary, deepmarine sediments, probably by bioturbation. The origin and distribution of oolitic sediments is discussed by Loreau and Purser, elsewhere in this volume.

\section{MUDDY SANDS}

Type no. 8 Lamellibranch muddy sand (Figs. 10 and 11)

(a) Sedimentologica1 description

The lamellibranch muddy sands consist of angular skeletal fragments and angular to rounded black compound grains in a muddy matrix. This sediment type has a wide spectrum of grain size and variation in constituent composition. Foraminifera and other skeletal fragments often show black infills or staining; the origin of the blackening is not fully understood (see Houbolt, 1957 and Sugden, 1966). 


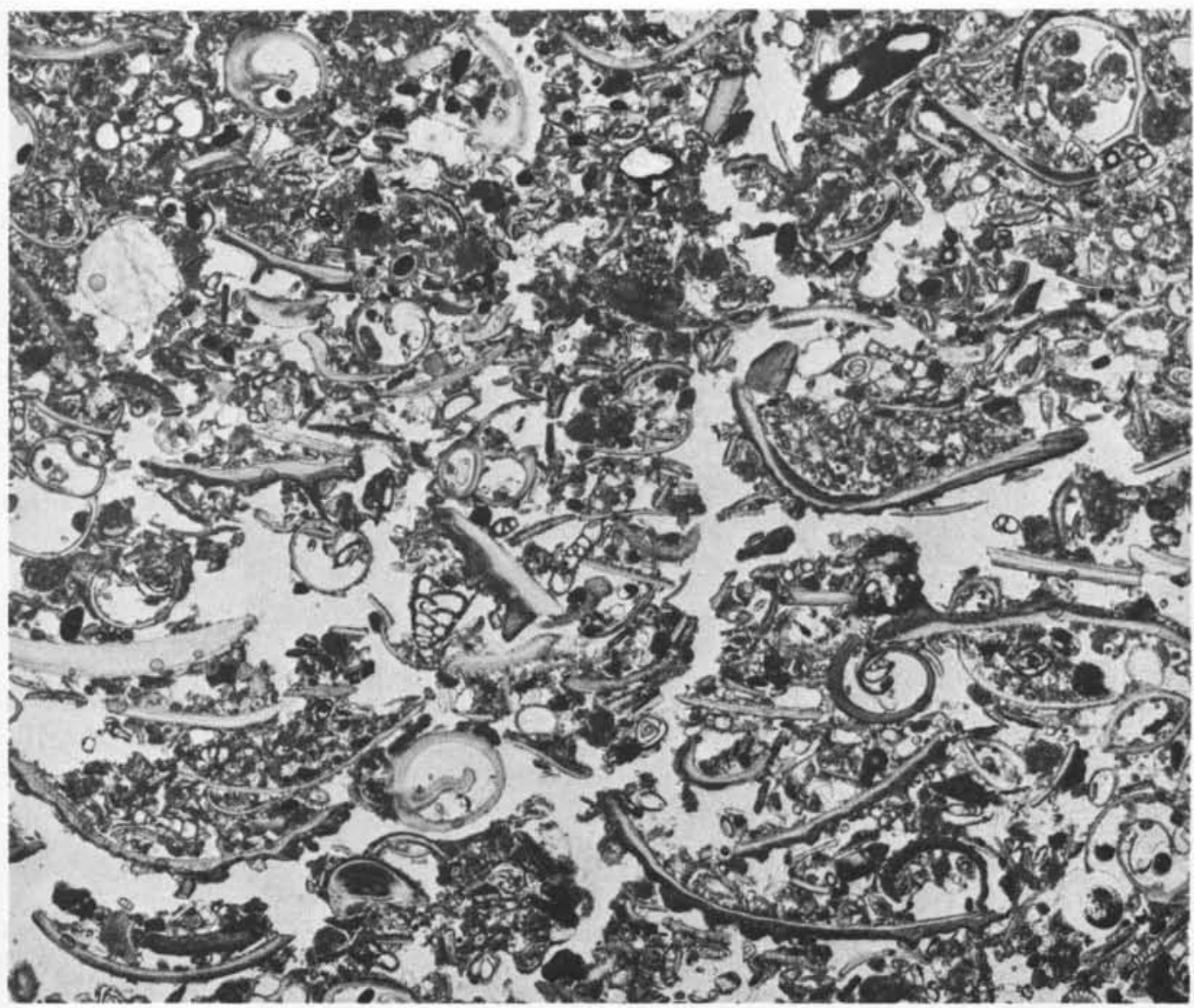

Fig. 12. Gastropod muddy sand - Thin section of sample T 1391, 14x

Bulk carbonate composition:

$\begin{array}{ll}\text { Aragonite } & 30 \% \\ \text { Mg calcite } & 60 \% \\ \text { Calcite } & 10 \%\end{array}$

Sorting: poor

Foraminiferal number: 3190
Grain size:

$\begin{array}{lr}>2 \mathrm{~mm} & 4 \% \\ 2-0.063 \mathrm{~mm} & 54 \% \\ <0.063 \mathrm{~mm} & 42 \%\end{array}$

Bulk insoluble residue: $18.3 \%$

Foraminiferal composition:

Calcareous imperforate $84 \%$

Calcareous perforate $16 \%$ 
The matrix averages $25 \%$ of the sediment. While bulk insoluble residue averages $3 \%$ and, in general, does not exceed $4 \%$, some samples show an exceptionally high bulk insoluble residue $(\mathrm{T} 111=14.5 \%, \mathrm{~T} 128=25.5 \%, \mathrm{~T} 938=12.6 \%)$.

(b) Fauna1/f1oral elements

Skeletal grains are mainly fragments of infaunal lamellibranchs (commonly the species Timoclea layardi), smaller Foraminifera, and echinoid fragments; the last occur particularly in the medium-sized muddy sands. In the finer sediments, soft faecal pellets may occur in varying quantities.

(c) Synsedimentary diagenetic features

Skeletal fragments in general do not show algally micritized peripheries.

(d) Re1ation to environment

$\mathrm{c}^{14}$ dating of the black particles in the sediment indicates that their age ranges from $3440 \pm 170$ to $4840 \pm 170$ years.

In any one sample they are invariably older than the non-blackened grains and may, in part, represent relict material.

The muddy lamellibranch sands occur in shallow marine, unrestricted, low-energy environments ranging in depth from 10 - 30 fathoms. They constitute widespread sheets between the highs on the Arabian homocline * and grade lateral$1 \mathrm{y}$ into muds in some of the deeper depressions.

Type no. 9 Gastropod muddy sand (Fig. 12)

(a) Sedimentological description

These sediments consist of poorly sorted, medium to coarse sand and gravelsized particles, comprising mainly gastropods, relatively unbroken lamellibranchs, imperforate Foraminifera, large compound grains (or lumps), and soft faecal pellets. Variable insoluble residues, mainly quartz, depend on proximity to aeolian sources.

(b) Fauna1/f1ora1 elements

These are essentially similar to those occurring within the gastropod sands.

(c) Synsedimentary diagenetic features

Particles are generally less "micritized" than the gastropod sands; unbroken lamellibranchs may have a fresh appearance. Incipient submarine lithification is rare, but in the Gulf of Salwa it can result in the widespread formation of irregularly shaped, gravel-sized lumps of lightly cemented rock.

(d) Relation to environment

Gastropod muddy sands favour lower energy, often restricted conditions and occur in very protected embayments, exemplified by the Gulf of Salwa, at depths down to $10 \mathrm{~m}$. Virtually all particles are indigenous to this environment.

* This term is defined and discussed in the introductory article in this volume by Purser and Seibold. 


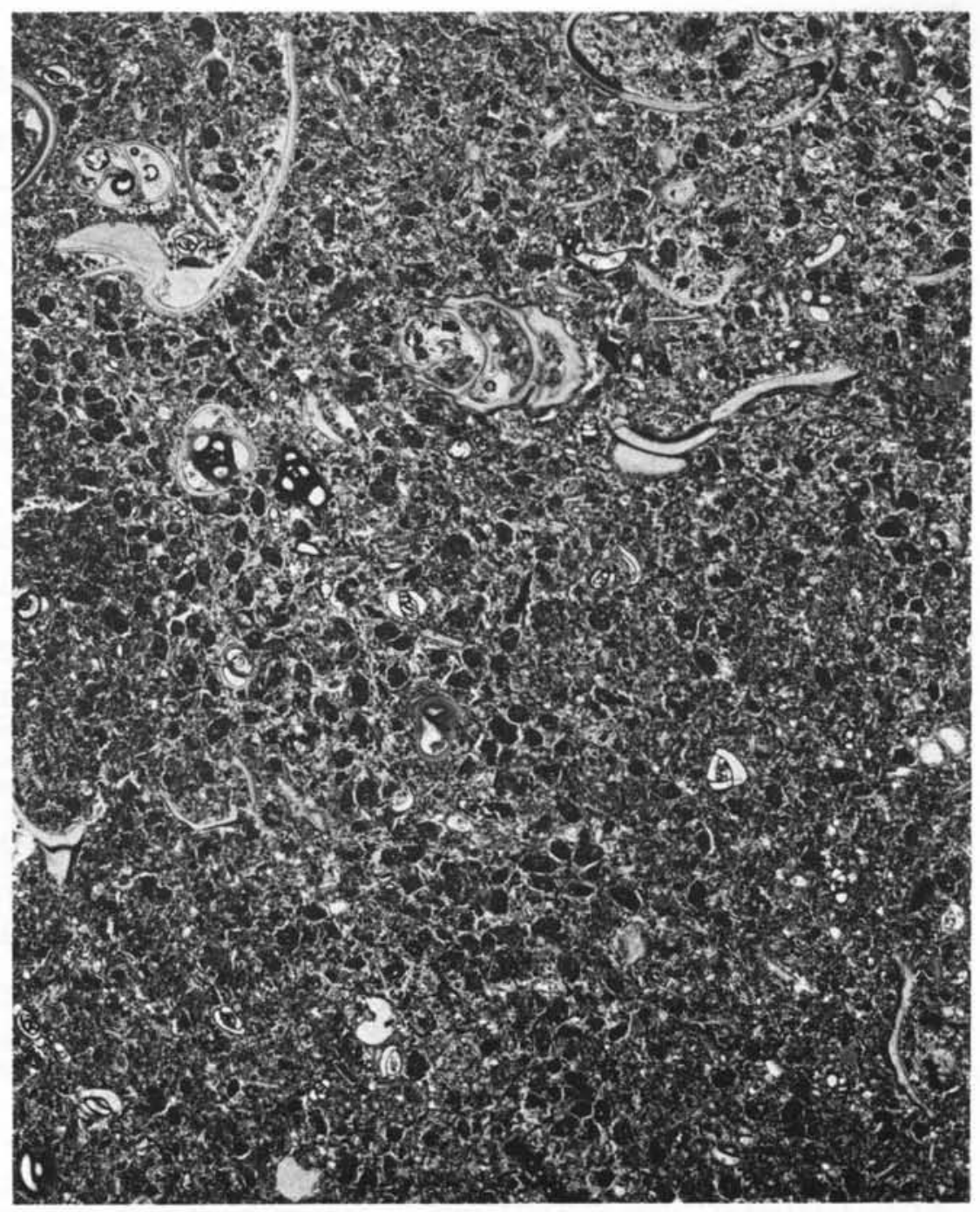

Fig. 13. Lamellibranch mud (ins. res. <10\%) - Thin section of sample $\mathrm{T} 805,10 \mathrm{x}$

Note: Abundant soft faecal pellets produced mainly by infaunal sediment feeders.

Blackening of some particles.

Bulk carbonate composition:

$\begin{array}{lr}\text { Aragonite } & 55 \% \\ \text { Mg calcite } & 30 \% \\ \text { Calcite } & 10 \% \\ \text { Dolomite } & 5 \%\end{array}$

Sorting: moderate to poor

Foraminiferal number: 2500
Grain size:

$\begin{array}{lr}>2 \text { m } & 2 \% \\ 2-0.063 \mathrm{~mm} & 25 \% \\ <0.063 \mathrm{~mm} & 73 \%\end{array}$

Bulk insoluble residue: $9 \%$

Foraminiferal composition:

Calcareous imperforate $84 \%$

Calcareous perforate $15 \%$

Arenaceous $\quad 1 \%$ 


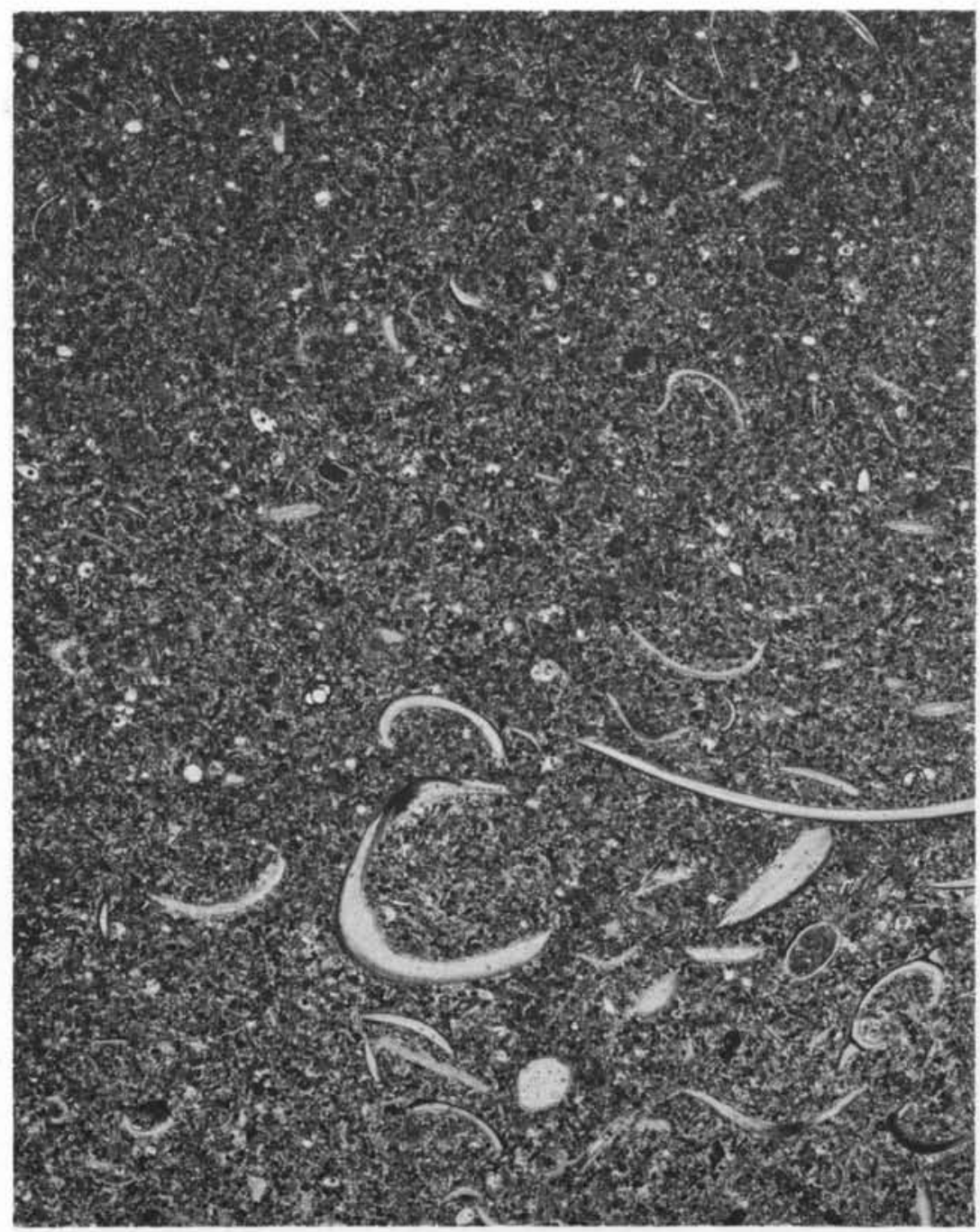

Fig. 14. Lamellibranch mud (ins. res. <10\%) - Thin section of sample $\mathrm{T} 22,10 \mathrm{x}$

Note: Overall resemblance with lamellibranch muddy sand shown in Fig. 11 (the sample is classified as a "mud" because matrix comprises more than $50 \%$ ).

Bulk carbonate composition:

$\begin{array}{ll}\text { Aragonite } & 55 \% \\ \text { Mg calcite } & 35 \% \\ \text { Calcite } & 10 \%\end{array}$

Sorting: poor

Foraminiferal number: 10,000
Grain size:

$\begin{array}{lr}>2 \mathrm{~mm} & 2 \% \\ 2-0.063 \mathrm{~mm} & 34 \% \\ <0.063 \mathrm{~mm} & 64 \%\end{array}$

Bulk insoluble residue: $4 \%$

Foraminiferal composition:

Calcareous imperforate $69 \%$ Calcareous perforate $17 \%$ Arenaceous $\quad 14 \%$ 
Type no. 10 Lamellibranch mud (ins. res. < 10\%) (Figs. 13 and 14 )

(a) Sedimentological description

The lamellibranch muds (i.r. < 10\%) contain whole or broken skeletal particles, some of which are blackened. The matrix averages $80 \%$, and bulk insoluble residue $6 \%$ of the bulk sediment.

(b) Fauna1/floral elements

Skeletal grains are mainly lamellibranch fragments and whole, small she11s. Determinable forms belong mainly to the genera Corbula, Nucula and Phacoides. Soft faecal pellets are sometimes abundant. Scanning-electron-microscope investigations revealed numerous coccoliths (see Hughes Clarke and Keij, this volume), but of one or two species only.

(c) Synsedimentary diagenetic features

Blackening of skeletal particles.

(d) Relation to environment

The mollusks and Foraminifera occurring in this sediment are infaunal and, for the greater part,indigenous. The lamellibranch mud accumulates as extensive patches in broad depressions, (10-20 fathoms) mainly on the proximal homocline. The presence of common coccoliths (plankton) in the lamellibranch mud is interesting partly because their abundance in ancient carbonates has often been interpreted as an indication of deeper-marine environments.

Type no. 11 Argillaceous lamellibranch mud (ins,res, > 10\%) Figs, 15 and 16)

(a) Sedimentological description

These sediments are distinguished from the preceding type only by their higher insoluble residue, which averages $21 \%$.

(b) Faunal/floral elements

Skeletal grains are mainly lamellibranch fragments, whole shells being essentially the same species as in type 10 lamellibranch muds. Scanning-electronmicroscope examination of the mud fraction of some samples reveals the presence of coccoliths.

(c) Synsedimentary features

Frequent blackening of grains.

(d) Re1ation to environment

Mollusks and Foraminifera occurring in the sediment are infaunal and indigenous to the environment of deposition. The black particles, including ooliths, give dates up to $12,200 \pm 400$ years $\mathrm{BP}$ and sometimes occur in large quantities.

Argillaceous lamellibranch muds are the most widespread sediments in the basin and occupy the deeper marine,distal homocline and axial areas. In the NW parts of the Gulf they apparently occur closer to the Arabian shore. Their distribution is probably the result of an interplay of two factors - proximity to siliciclastic source, and higher carbonate production in the shallow proximal parts of the marine homocline. 


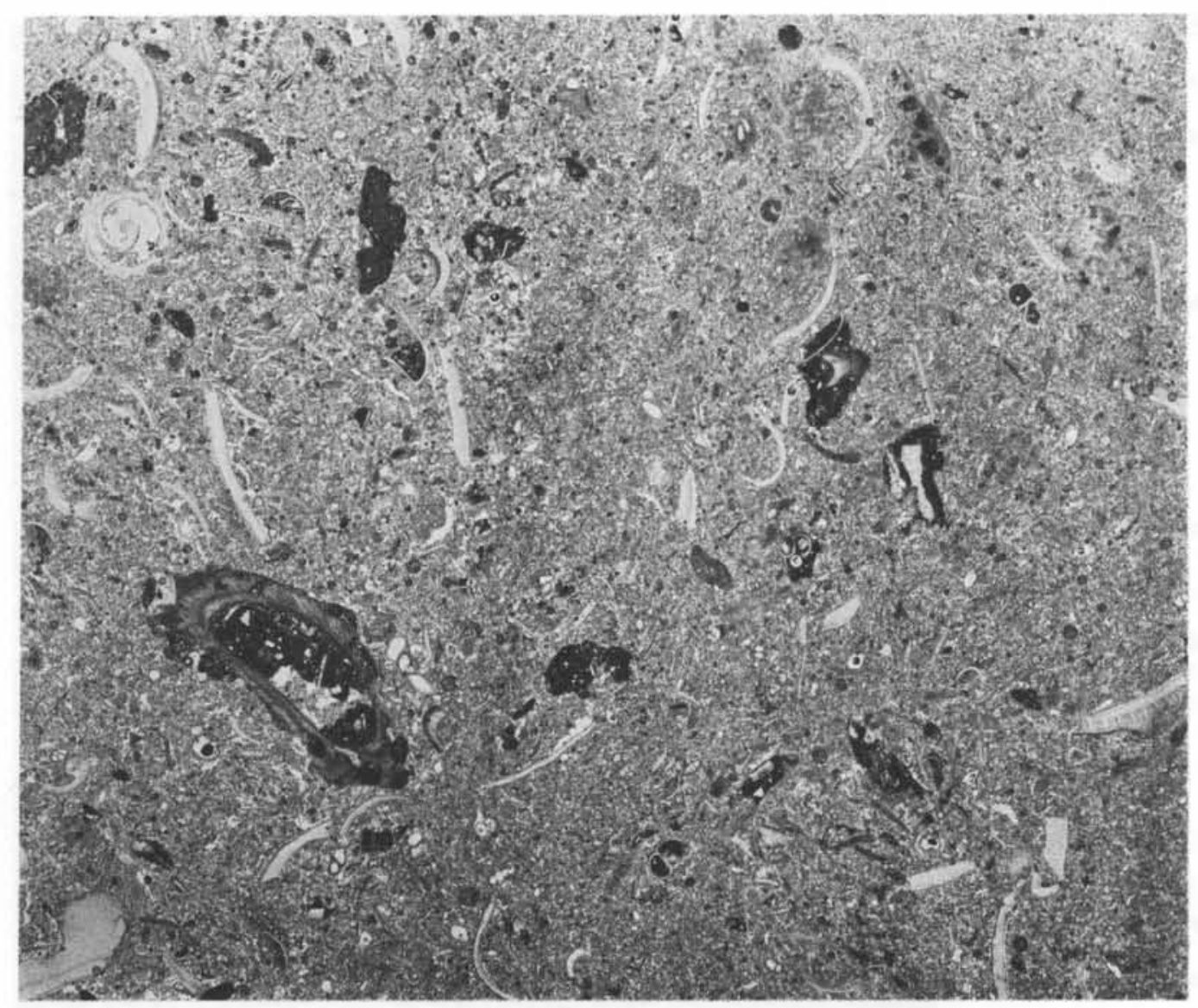

Fig. 15. Argillaceous lamellibranch mud (ins. res. $>10 \%$ )

Thin section of sample T $860,10 x$

Note: Occurrence of "black" particles (relict)

Bulk carbonate composition:

$\begin{array}{ll}\text { Aragonite } & 40 \% \\ \text { Mg calcite } & 35 \% \\ \text { Calcite } & 15 \%\end{array}$

Sorting: poor

Foraminiferal number: 900
Grain size:

$\begin{array}{lr}>2 \mathrm{~mm} & 2 \% \\ 2-0.063 \mathrm{~mm} & 22 \% \\ <0.063 \mathrm{~mm} & 76 \%\end{array}$

Bulk insoluble residue: $17 \%$

Foraminiferal composition:

Calcareous imperforate $35 \%$

Calcareous perforate $35 \%$

Arenaceous $29 \%$

Planktonic

$1 \%$ 


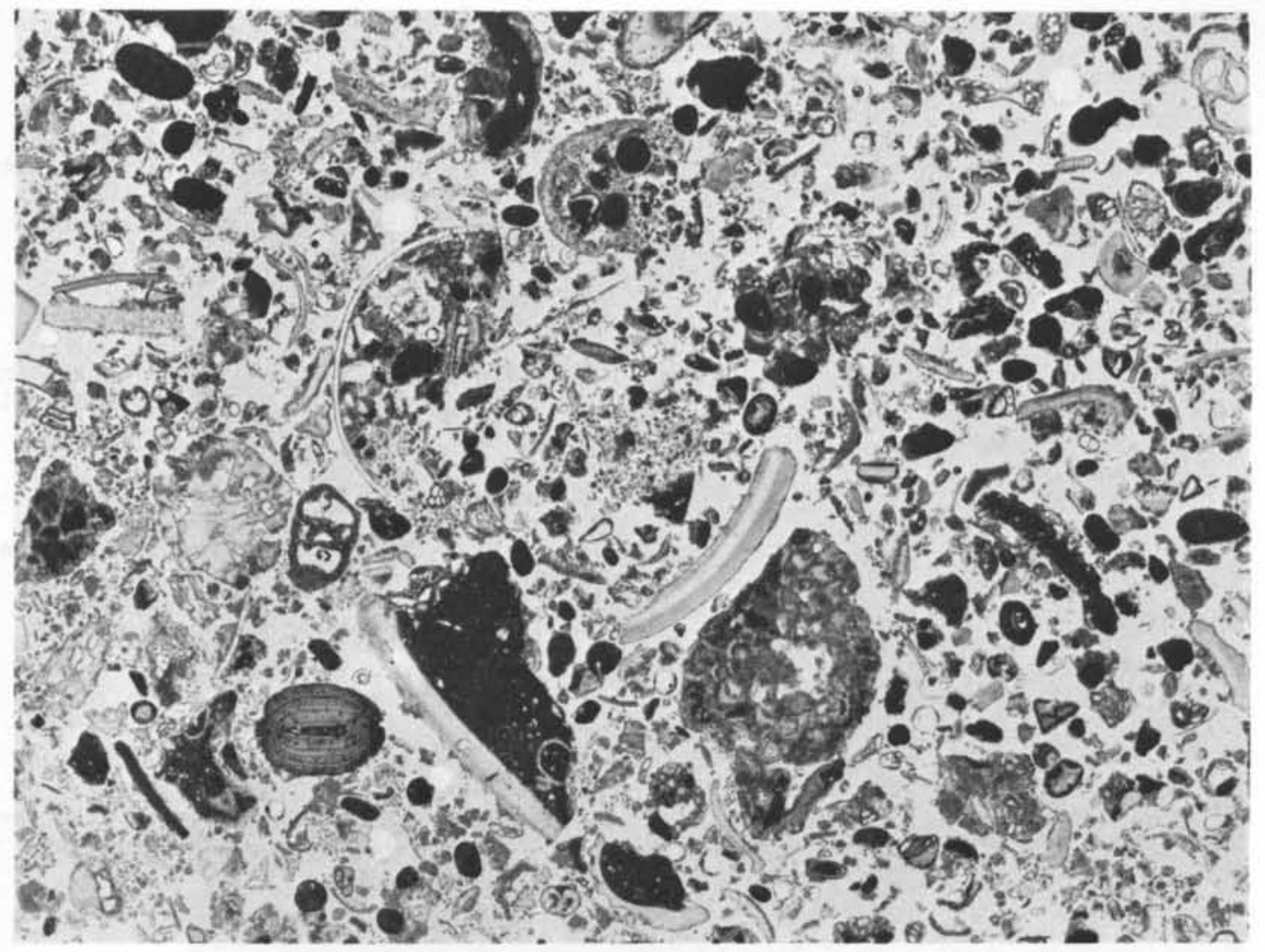

Fig. 16. Argillaceous lamellibranch mud (ins. res. $>10 \%$ )

Thin section of sample T 1297, 10x

Note: Photographed area of sample actually constitutes a muddy sand; numerous "black" particles (i.e. ooids) are relict.

Bulk carbonate composition:

$\begin{array}{lr}\text { Aragonite } & 50 \% \\ \text { Mg calcite } & 30 \% \\ \text { Calcite } & 15 \% \\ \text { Dolomite } & 8 \%\end{array}$

Sorting: moderate

Foraminiferal number: 2900
Grain size:

$\begin{array}{rr}>2 \mathrm{~mm} & 13 \% \\ 2-0.063 \mathrm{~mm} & 63 \% \\ 0.063 \mathrm{~mm} & 34 \%\end{array}$

Bulk insoluble residue: $7.7 \%$

Foraminiferal composition:

Calcareous imperforate $14 \%$

Calcareous perforate $50 \%$

Arenaceous $\quad 24 \%$

Planktonic $\quad 12 \%$ 
Type no. 12 Imperforate foraminiferal/gastropod mud (Fig. 17)

\section{(a) Sedimentological description}

The sediment consists of 1ight-grey carbonate mud with scattered skeletal grains dominated by imperforate Foraminifera. The mud may be extensively pelleted and when dried may appear as a pelletal sand. Artificial compaction of the soft pellets gives a "clotted" texture. Insoluble residues are less than $5 \%$ except when close to an aeolian source.

(b) Faunal/floral elements

The sediments are characterized by a uniform low-diversity fauna consisting of miliolid and peneroplid Foraminifera, of ten with cerithid gastropods and small lamellibranchs.

(c) Synsedimentary diagenetic features

These are generally absent. Grains are fresh in appearance and rarely have algally bored peripheries. Boring micro-algae are probably inhibited by the infaunal mode of life of most mollusks, or by the rapid burial of the skeletal grains.

(d) Relation to environment

These sediments occur in highly protected, shallow-water $(<5 \mathrm{~m})$ environments within coastal embayments and on the lee sides of barrier complexes. Salinities in these environments frequently exceed $50 \mathrm{ppm}$ and, together with the strongly fluctuating water temperatures, probably account for the monotony of the fauna characterising these sediments.

\section{NON-CARBONATES}

Type no. 13 guartz sand and muddy quartz sand

\section{(a) Sedimentological description}

These sediments consist of we11-sorted and rounded quartz and subsidiary carbonate grains with minor amounts of angular skeletal debris. They are generally characterized by large-scale, unidirectional cross-bedding and grade downwards into muddy (carbonate), finer quartz sands. The latter lack cross-bedding, are bioturbated, and can contain numerous angular skeletal fragments. *

(b) Faunal/floral elements

The cross-bedded quartz sands, although deposited in a marine environment, contain only rare,scattered mollusk fragments and occasional miliolid Foraminifera. The muddy quartz sands contain a richer fauna of mollusks, scattered burrowing echinoids, and miliolids.

(c) Synsedimentary diagenesis

Where these sands occur in supratidal environments, they frequently contain poikilitic gypsum and traces of Holocene dolomite.

(d) Relation to environment

In the Persian Gulf, where carbonate sedimentation is dominant, relatively

* For photographs and further discussion of these sands, see contribution by Shinn in this volume. 


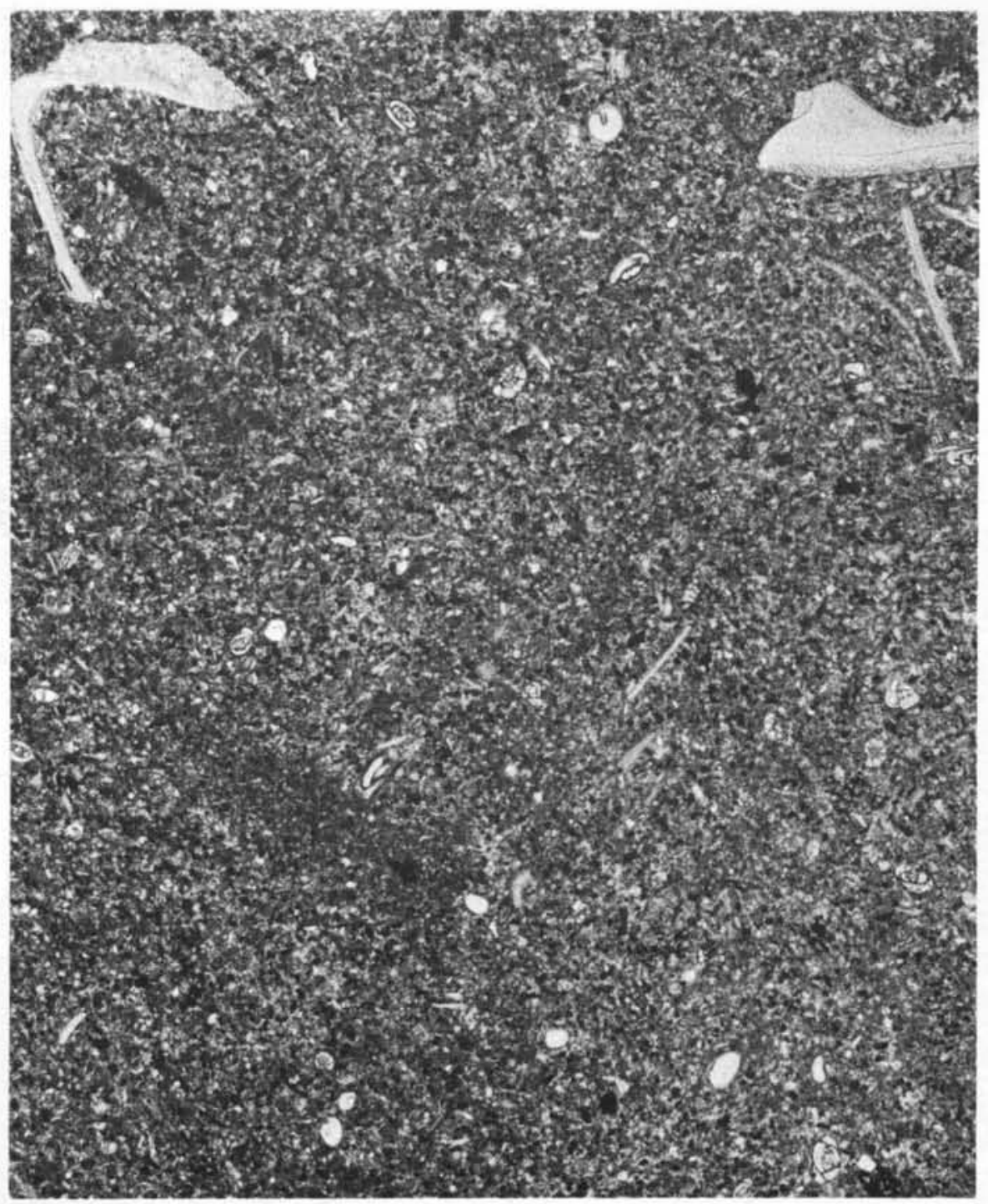

Fig. 17. Imperforate for aminiferal/gastropod mud

Bulk carbonate composition:

$\begin{array}{ll}\text { Aragonite } & 20 \% \\ \text { Mg calcite } & 50 \% \\ \text { Calcite } & 30 \%\end{array}$

Sorting: poor

Foraminiferal number: 3220
- Thin section of sample D 719, 15x

Grain size:

$\begin{array}{lr}>2 \mathrm{~mm} & 1 \% \\ 2-0.063 \mathrm{~mm} & 10 \% \\ <0.063 \mathrm{~mm} & 89 \%\end{array}$

Bulk insoluble residue: $16.9 \%$

Foraminiferal composition:

Calcareous imperforate $\quad 77 \%$

Calcareous perforate $23 \%$ 
pure siliciclastic sands are accumulating in the marine environments only along lee coasts. This situation is typified by the SE coast of Qatar Peninsula, where quartz dune sand is blown into the adjacent inter- and shallow subtidal coastal areas. This sand grades seawards into fine muddy quartz sand, and finally into autochthonous carbonate muds (discussed by Shinn, in this volume).

\section{Type no. 14 Sedimentary gypsum}

\section{(a) Sedimentological description}

When gypsum is precipitated from standing water in highly restricted lagoons, it accumulates as thin crusts interbedded with the prevailing sediments; these are often aeolian.

Sedimentary structures have not been recognized.

(b) Fauna1/floral elements

In the single area examined in any detail (Khor Odaid, SE Qatar), the highly impoverished fauna consisted only of one species of the ostracod genus Cyprideis.

(c) Synsedimentary diagenetic features

None are known (unless one regards the gypsum precipitate itself as a diagenetic product).

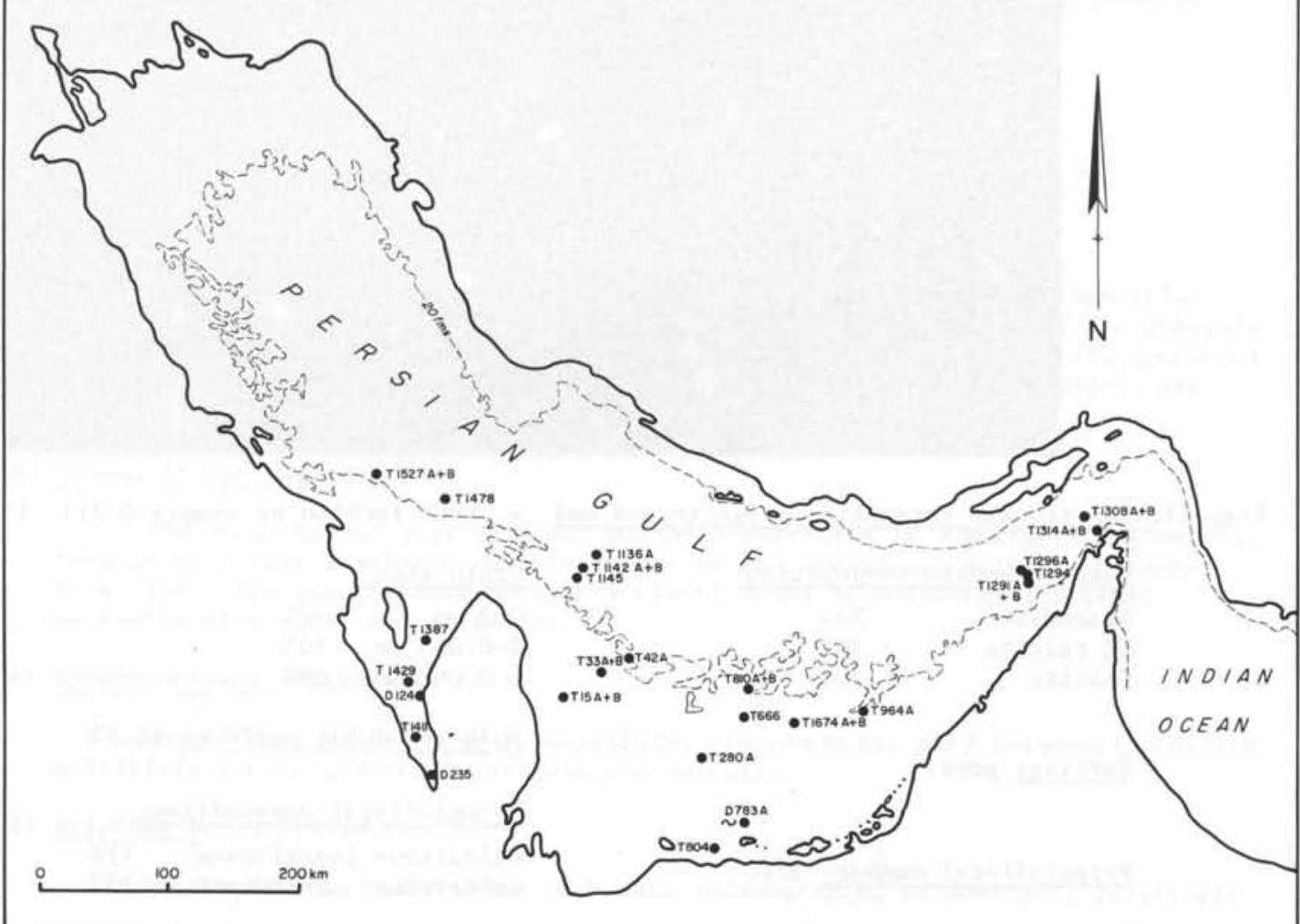

Fig. 18. Location of samples dated by carbon-14 


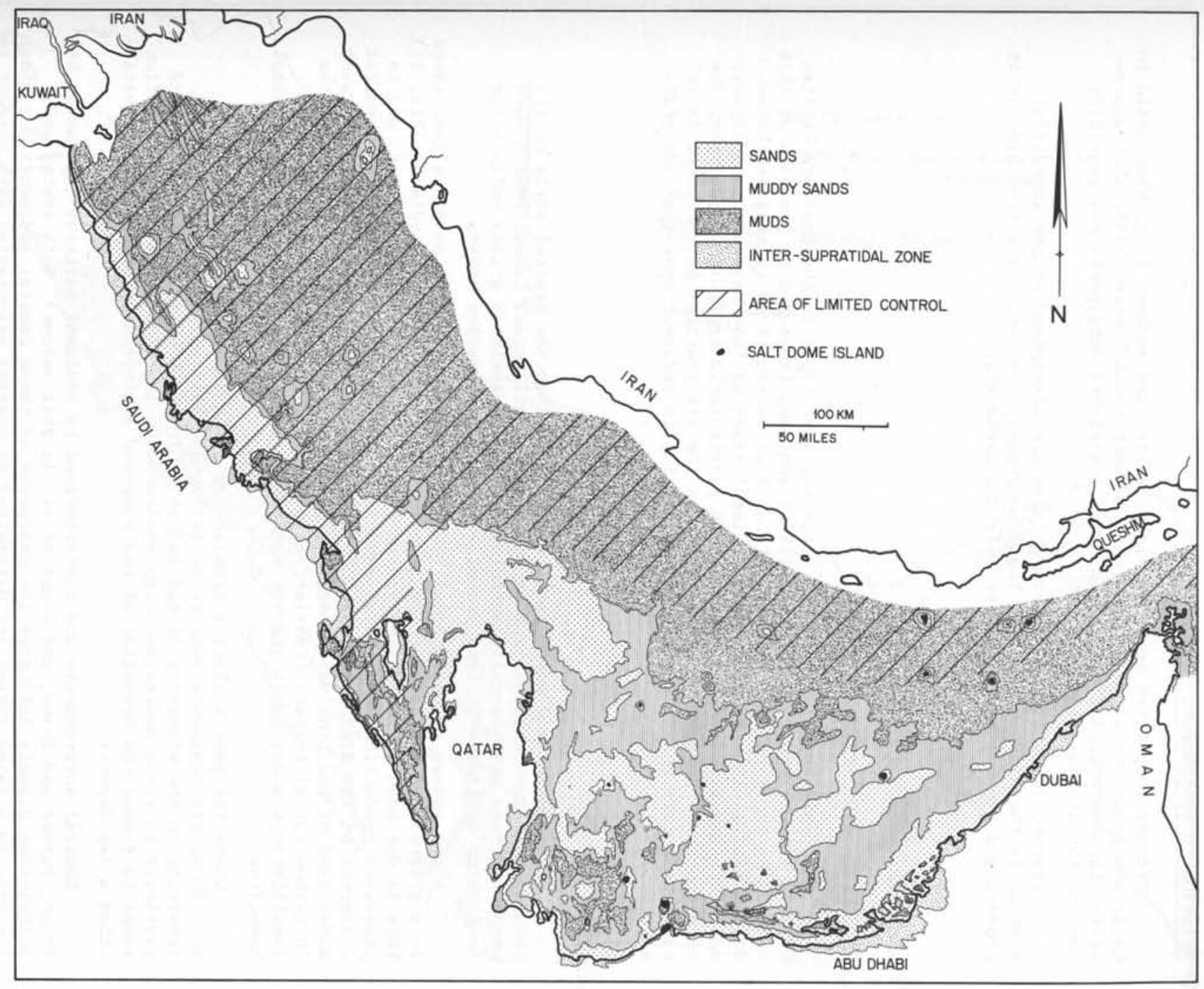

Fig. 19. Regional distribution of principal sedimentary textures 
(d) Relation to environment

Primary evaporites occur in highly restricted lagoons (e.g. Khor Odaid in Qatar and Dohat Dhulum in Saudi Arabia, Bramkamp and Powers, 1955). Such supersaline lagoons occur at the ends of long restricted embayments and generally have depths of less than $2 \mathrm{~m}$.

Gypsum, anhydrite and celestine also are widespread on the supratidal sabkhas in the SE Persian Gulf. These sulphates, however, are a true diagenetic product and generally replace pre-existing carbonate.

\section{DISTRIBUTION OF THE SEDIMENTS}

A. The map and profiles

The distribution of the described sediment types in the Southern Persian Gulf is illustrated by means of profiles and maps (appended at the back of this volume). In constructing the maps, it has been necessary to generalise the observed distribution of individual sediment types as this may vary rapidly over short distances, especially in areas of particularly irregular topography. The occurrence of the sediment types shown on the six profiles is therefore to be taken as a more accurate guide to variability in sediment type than the sediment map.

\section{B. General trends}

From the map and profiles it can be seen that the central parts of the Persian Gulf are characterized by widespread argillaceous lamellibranch muds whose textures and generally unbroken or angular skeletal grains reflect the low-energy environments that prevail in these deep-marine areas.

A one passes up the Arabian homocline towards the Arabian shoreline, there is a progressive increase in the granular fraction within the sediment (Fig. 19). This is due both to increasing energy conditions with winnowing of mud, and to increases production of skeletal carbonate. The rapid change from mud-supported sediments of the distal homocline to essentially grain-supported, lamellibranch muddy sand of the proximal homocline, generally coincides with the foot of the 20 fathom $(36 \mathrm{~m}$ ) terrace (Kassler, this volume). The relatively low-energy, lamellibranch muddy sands are the most widespread sediment type on the proximal homocline.

Where the gently sloping Arabian sea floor is situated at depths of 10 - $20 \mathrm{~m}$, its sediments seem to be influenced only slightly by wave action, resulting in the winnowing of mud and silt. The lack of transport of the sand particles in these moderate-energy environments and slow rates of sedimentation seems to favour the formation of the compound grain/lamellibranch sands constituting a lag deposit.

Coastal environments are characterized by sediment patterns (discussed by Shinn, Purser and Evans, and Evans et al. in this volume). Both energy and restriction clearly influence the character of these coastal sediments and these factors, to a large extent are determined by coastal orientation with respect to the strong $\mathrm{NW}^{\prime}$ winds, and by the presence or absence of offshore barriers.

Because most of the Arabian coast is exposed to the NW "shemal" winds, its sediments are largely high-energy, mainly (broken) lamellibranch sands. These are locally replaced by ooidal sands which are especially well developed at the seawards ends of tidal channels in Abu Dhabi, and by coral/algal fringing reefs and associated coral/algal sands in the most exposed, windward coastal settings, e.g. the $\mathrm{N}$ end of Qatar Peninsula. 


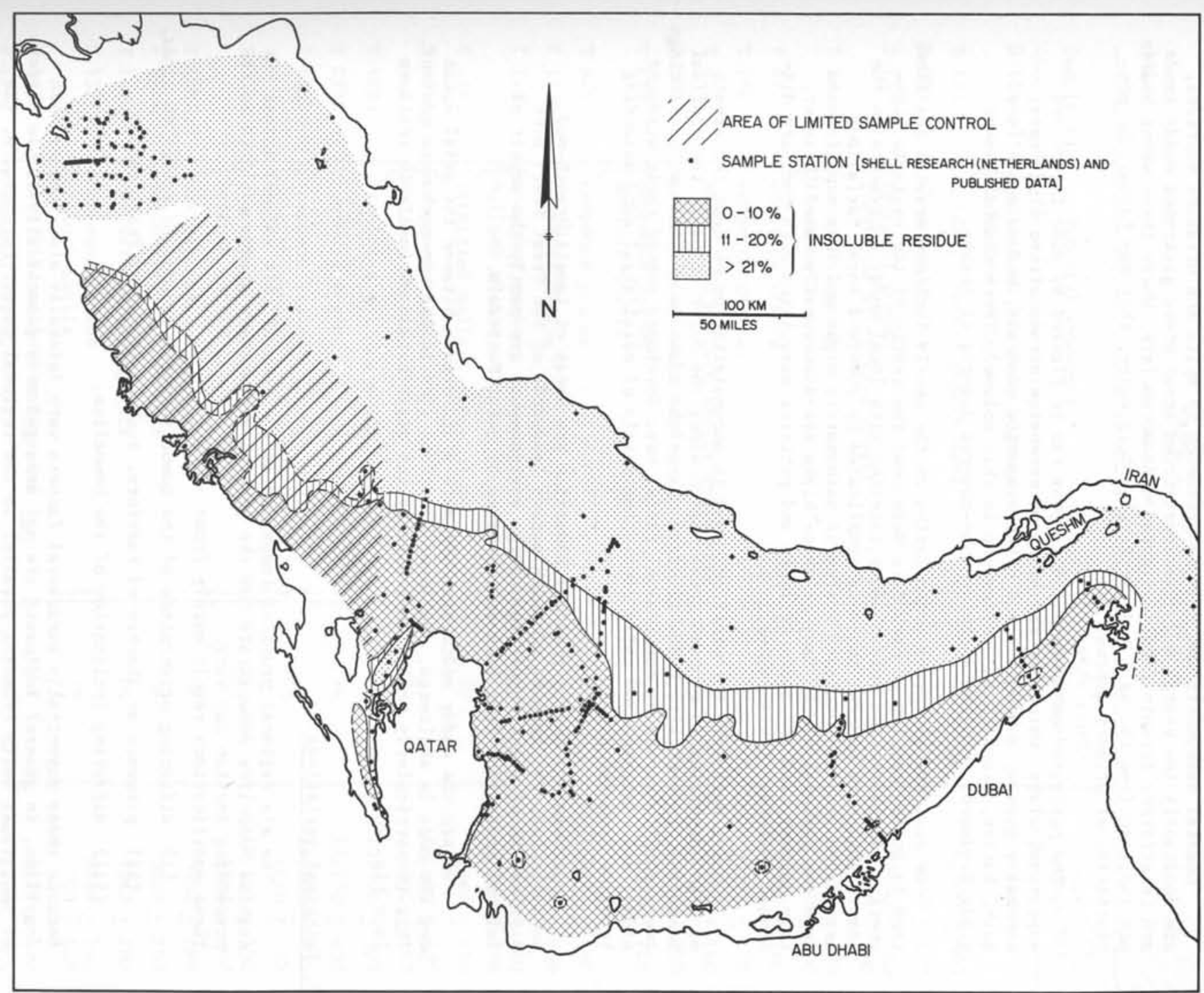

Fig. 20. Regional distribution of insoluble residues 
Coastal embayments and lagoons protected by spits and offshore barriers, are dominant1y low energy and often restricted areas where gastropod muddy sands and imperforate foraminiferal/gastropod muds accumulate. Where these water bodies are isolated from the main body of Persian Gulf water, they may favour the precipitation of primary gypsum.

The protected embayments and lagoons can be flanked by wide inter- and supratidal flats which are the sites of extensive stromatolitic algal mats, secondary gypsum, anhydrite, and other evaporite minerals, and dolomite (see Bush, Butler, Evans et al., elsewhere in this volume). These coastal swamps grade landwards into the rocky or dune-covered deserts of Arabia.

In sum, the sediments accumulating on the gently inclined Arabian sea floor tend to grade from impure carbonate muds near the centre of the basin to highenergy, bioclastic and ooidal sands, together with local muddy embayments on the coast. This very general trend is complicated by numerous local variations associated with an intricate system of bathymetric highs and lows superimposed upon the regional slope. Many of these highs are structurally based (Kassler, this volume), and the sediment types and patterns associated with them are discussed by Purser (this volume).

Large perforate foraminiferal sand is accumulating on, or near, the crests of highs occurring in exposed areas, often along the outer edges of the proximal homocline. In contrast, highs situated nearer the coast in shallow-marine settings are generally capped by coral/algal reefs, best developed around their windward sides, and elongate sand tails consisting mainly of coral/algal sand extending leewards from the highs.

Depressions on the proximal homocline are areas of lamellibranch-mud accumulation. The largest of these occurs landwards of the Great Pearl Bank barrier, SE of Qatar, where low-energy environments are partly the result of lateral protection from wind-driven waves by Qatar Peninsula.

Within the muddy sediments, the marked difference between the axial areas and the muds in sheltered, shallower locations lies in the non-carbonate content. This is particularly well illustrated by the distribution of insoluble residues (see Fig. 20).

\section{Principal variations}

The six regional profiles (appended at the back of this volume) across the Arabian homocline demonstrate how the general sedimentary trends outlined in the preceeding section may vary.

These modifications result mainly from:

(i) differing orientation of the homocline with respect to strong NW winds,

(ii) presence or absence of barriers, such as the Great Pearl Bank,

(iii) differing inclination of the homocline.

Because these essentially structural factors vary laterally along the Arabian coastline, in general sediments are not arranged in a geometically simple pattern of individual belts trending paralle $\overline{1}$ to the regional coast. Furthermore, the complexity of sediment pattern increases towards the coastline. 
TABLE I. $\mathrm{C}^{14}$ DATINGS

(see also Fig. 18)

\begin{tabular}{|c|c|c|c|}
\hline Samp1e no. & Material examined & $\begin{array}{l}\text { Water depth } \\
\text { in metres }\end{array}$ & $\begin{array}{c}\text { Age }\left(\mathrm{C}^{14}\right) \\
\text { (years } \mathrm{BP})\end{array}$ \\
\hline D 124 & $\left\{\begin{array}{l}\text { mollusk shells from lightly } \\
\text { lithified sediment }\end{array}\right.$ & 18 & $<240$ \\
\hline D 235 & ooidally coated quartz sand & 4 & $11.100 \pm 400$ \\
\hline D 783 & compound grains & 9 & $4840 \pm 170$ \\
\hline T 15 & $\left\{\begin{array}{l}\text { compound grains } \\
\text { fresh and micritized shells }\end{array}\right.$ & 16 & $\begin{aligned} & 3440 \pm 170 \\
& 190 \pm 120\end{aligned}$ \\
\hline T 33 & $\left\{\begin{array}{l}\text { compound grains } \\
\text { fresh mollusk shells }\end{array}\right.$ & 24 & $\begin{array}{r}4200 \pm 170 \\
290 \pm 140\end{array}$ \\
\hline T 42 & compound grains & 28 & $2460 \pm 140$ \\
\hline T 280 & compound grains & 19 & $3540 \pm 170$ \\
\hline T 666 & micritized mollusk shells and debris & 16 & $300 \pm 140$ \\
\hline T 804 & rounded bioclastic sand & 6 & $980 \pm 150$ \\
\hline T 810 & $\left\{\begin{array}{l}\text { compound grains } \\
\text { mollusk shells }\end{array}\right.$ & 23 & $2360 \pm 140$ \\
\hline T 964 & compound grains & 20 & $2180 \pm 150$ \\
\hline Т 1136 & compound grains & 50 & $8830 \pm 260$ \\
\hline Т 1142 & $\left\{\begin{array}{l}\text { compound grains } \\
\text { mollusk shells }\end{array}\right.$ & 41 & $\begin{array}{r}7820 \pm 240 \\
760 \pm 140\end{array}$ \\
\hline T 1145 & 1ithified mollusk muddy sand & 37 & $2880 \pm 170$ \\
\hline T 1291 & $\left\{\begin{array}{l}\text { compound grains } \\
\text { mollusk shells }\end{array}\right.$ & 67 & $\begin{array}{r}14.400 \pm 400 \\
4000 \pm 180\end{array}$ \\
\hline T 1294 & 1ithified mollusk muddy sand & 68 & $10.700 \pm 300$ \\
\hline T 1296 & compound grains & 76 & $12.200 \pm 400$ \\
\hline Т 1308 & $\left\{\begin{array}{l}\text { compound grains } \\
\text { mollusk shells }\end{array}\right.$ & 86 & $\begin{array}{r}12.100 \pm 300 \\
2820 \pm 150\end{array}$ \\
\hline T 1314 & $\left\{\begin{array}{l}\text { compound grains } \\
\text { mollusk shells }\end{array}\right.$ & 103 & $\begin{array}{r}12.500 \pm 400 \\
1340 \pm 140\end{array}$ \\
\hline T 1387 & mollusk shell fragments & 6 & $3050 \pm 180$ \\
\hline T 1411 & mollusk she11 fragments & 8 & $3810 \pm 220$ \\
\hline T 1429 & mollusk she11 fragments & 18 & $5380 \pm 260$ \\
\hline T 1527 & $\left\{\begin{array}{l}\text { compound grains } \\
\text { mollusk shells }\end{array}\right.$ & 36 & $\begin{aligned} 3020 & \pm 160 \\
590 & \pm 140\end{aligned}$ \\
\hline T 1478 & lithified mollusk muddy sand & 41 & $2120 \pm 150$ \\
\hline T 1674 & $\left\{\begin{array}{l}\text { compound grains } \\
\text { mollusk shells }\end{array}\right.$ & 32 & $\begin{array}{r}8340 \pm 240 \\
950 \pm 130\end{array}$ \\
\hline
\end{tabular}

